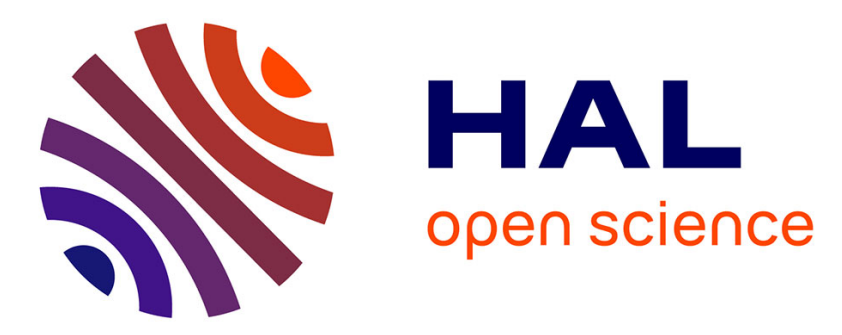

\title{
Nutrient trapping in the equatorial Pacific: The ocean circulation solution
}

\author{
Olivier Aumont, James C. Orr, Patrick Monfray, Gurvan Madec, Ernst \\ Maier-Reimer
}

\section{- To cite this version:}

Olivier Aumont, James C. Orr, Patrick Monfray, Gurvan Madec, Ernst Maier-Reimer. Nutrient trapping in the equatorial Pacific: The ocean circulation solution. Global Biogeochemical Cycles, 1999, 13, pp.351-369. 10.1029/1998GB900012 . hal-00772180

\section{HAL Id: hal-00772180 \\ https://hal.science/hal-00772180}

Submitted on 17 Sep 2020

HAL is a multi-disciplinary open access archive for the deposit and dissemination of scientific research documents, whether they are published or not. The documents may come from teaching and research institutions in France or abroad, or from public or private research centers.
L'archive ouverte pluridisciplinaire HAL, est destinée au dépôt et à la diffusion de documents scientifiques de niveau recherche, publiés ou non, émanant des établissements d'enseignement et de recherche français ou étrangers, des laboratoires publics ou privés. 


\title{
Nutrient trapping in the equatorial Pacific: The ocean circulation solution
}

\author{
O. Aumont, J. C. Orr, and P. Monfray \\ Laboratoire des Sciences du Climat et de l'Environnement, Gif sur Yvette, France \\ G. Madec \\ Laboratoire d'Océanographie Dynamique et de Climatologie, CNRS/ORSTOM/UPMC \\ Université Paris VI, Paris, France \\ E. Maier-Reimer \\ Max Planck Institut für Meteorologie, Hamburg, Germany
}

\begin{abstract}
Nutrient trapping is a chronic problem found in global carbon cycle models with particle-only remineralization schemes. It is defined as the excess of subsurface nutrient concentrations relative to observations and occurs principally in the eastern equatorial Pacific. Previous studies reduced excess simulated nutrients by increasing the complexity of modeled biogeochemistry, i.e., by adding pools for nutrients (and carbon) either in dissolved organic form or as plankton. Conversely, our study suggests that deficiencies in modeled circulation fields from global coarseresolution ocean models are mostly responsible. This new interpretation stems from our use of an ocean general circulation model with higher resolution, which offers a more realistic equatorial circulation. We used the same biogeochemical model Hamburg ocean carbon cycle model, version 3, as in some of the previous studies. Our model-predicted distribution of $\mathrm{PO}_{4}^{3-}$ in the equatorial Pacific agrees reasonably well with the observations both at the surface and in the subsurface. Subsurface $\mathrm{PO}_{4}^{3-}$ concentrations in our model's eastern equatorial Pacific exceed observations by, at most, $15 \%$, unlike coarser-resolution models. Improvement is due to enhanced meridional resolution $\left(0.5^{\circ}\right)$ near the equator, which allows the model to simulate a vigorous equatorial undercurrent that brings in low-nutrient water from the western basin. Furthermore, the model upwells no nutrient-rich abyssal water into the surface equatorial Pacific. Our results suggest that dissolved organic carbon plays a minor role in the carbon budget of the equatorial Pacific.
\end{abstract}

\section{Introduction}

The equatorial Pacific provides the largest source of $\mathrm{CO}_{2}$ from the ocean to the atmosphere. The winddriven equatorial divergence drives the upwelling of $\mathrm{CO}_{2}$-rich subsurface water to the surface, thereby inducing an outgassing of $0.4-0.9 \mathrm{Pg} \mathrm{Cyr}^{-1}$ [Gammon et al., 1985; Wong et al., 1993], mostly in the eastern and central Pacific. The corresponding large subsurface supply of nutrient maintains intense biological activity, perhaps representing up to $58 \%$ of the global new production [Chavez and Barber, 1987]. Presumably, the

Copyright 1999 by the American Geophysical Union.

Paper number 1998 GB900012.

0886-6236/99/1998GB900012\$12.00 equatorial Pacific's new production could be even higher if the high levels of surface nutrients, abnormal for most of the ocean, could be used more efficiently. Production appears limited in the equatorial Pacific owing to an insufficient supply of iron [Coale et al., 1996]. The equatorial Pacific is known for large interannual variability in ocean circulation and air-sea fluxes of $\mathrm{CO}_{2}$. When upwelling weakens during El Niño-Southern Oscillation (ENSO) warm events, this source of $\mathrm{CO}_{2}$ may almost completely vanish [Wong et al., 1993].

Global coarse-resolution ocean models coupled to simple biogeochemical models have been used to improve understanding of the ocean's carbon cycle [Najjar, 1990; Bacastow and Maier-Reimer, 1991; Najjar et al., 1992; Maier-Reimer, 1993; Anderson and Sarmiento, 1995; Yamanaka and Tajika, 1996; Six and Maier-Reimer, 1996]. Despite the ability of such coarse-resolution 
ocean general circulation models (OGCMs) to reproduce the large-scale features of observed tracers such as ${ }^{14} \mathrm{C}$, previous attempts have failed when it comes to simulating realistic nutrients near the equator with a simple particle-only remineralization scheme. All such forward models have simulated excess nutrient concentrations below areas of intense biological production; model-predicted nutrients exceed observations by at least $50 \%\left(1.5 \mu \mathrm{mol} \mathrm{L}^{-1}\right)$, particularly in the eastern equatorial Pacific [Bacastow and Maier-Reimer, 1990; Najjar et al., 1992; Maier-Reimer, 1993; Yamanaka and Tajika, 1997]. This flaw, termed "nutrient trapping" by Najjar [1990], results from a positive feedback between intense production induced by the upwelling of nutrient-rich abyssal waters and remineralization of organic matter within the divergence.

To remedy this model artifact, efforts have focused on apparent oversimplifications in modeled biogeochemistry. The first proposed biogeochemical remedy for nutrient trapping was motivated by new measurements of surprisingly large concentrations of dissolved organic carbon (DOC) [Suzuki et al., 1985; Sugimura and Suzuki, 1988]. Ocean modelers who added a large, long-lived DOC pool to their particle-only models did indeed find substantial reduction in nutrient trapping [Najjar, 1990; Bacastow and Maier-Reimer, 1990; Najjar et al., 1992; Anderson and Sarmiento, 1995]. Adding a DOC pool decreases the amount of nutrients exported to depth by particles. Because it is long lived, much of the DOC is exported laterally away from the problematic equatorial Pacific. Analytical problems were eventually shown to be the cause of the high measured DOC [Suzuki, 1993]. Modelers had to find another solution to the nutrient-trapping artifact.

Six and Maier-Reimer [1996] have proposed a second solution to nutrient trapping. They have also suggested that an oversimplified ocean biogeochemistry is to blame. To improve matters, their new biogeochemical model includes interactions between phytoplankton and zooplankton, as well as a reservoir of semilabile DOC having a much shorter lifetime than that used previously. As a result, in the eastern equatorial Pacific Ocean, the presence of a large standing stock of zooplankton reduces primary production and resulting export production. Additionally, a significant part of the organic matter is exported laterally as DOC away from the divergence. Combination of both factors (zooplankton grazing and horizontal DOC transport) reduces accumulation of nutrient below the divergence.

Another possibility, that faulty model circulation fields may cause nutrient trapping has not been explored previously with simulations in OGCMs, which, by definition, predict a three dimensional (3-D) ocean circulation field. However, Matear and Holloway [1995] suggest that the OGCM circulation fields may be partly to blame. Simulated subsurface nutrient concentra- tions in their adjoint model become more realistic when they stipulate that the $10 \mathrm{~Sv}$ upwelling in their original advection field, taken from the Hamburg large-scale geostrophic (LSG) model [Maier-Reimer et al., 1993], is replaced by downwelling. That coarse-resolution models overpredict equatorial upwelling has been suggested for some time [Toggweiler et al., 1991]. Although Matear and Holloway [1995] seem to have identified one potential problem, more refined OGCM's are needed to determine the causes of this and other circulation deficiencies, which may contribute to nutrient trapping.

With such in mind, we have compared simulations from two very different OGCMs that have both used one common biogeochemistry. For our study, we implanted the Hamburg ocean carbon cycle model (HAMOCC3) developed by Maier-Reimer [1993] in OPA (Océan Parallélisé), an ocean general circulation model developed at the Laboratoire d'Océanographie Dynamique et de Climatologie (LODYC) in Paris. Then we compared our results to those obtained previously, with runs of HAMOCC3 in the LSG model from Maier-Reimer [1993].

We found that the OPA-HAMOCC3 model produces little nutrient trapping (model predictions exceed observed $\mathrm{PO}_{4}^{3-}$ by $15 \%$, at most); the LSG-HAMOCC3 combination [Maier-Reimer, 1993] produces larger excesses (up to $100 \%$ ). In the equatorial Pacific, OPA's high resolution and its prognostic parameterization of vertical turbulence provide circulation fields that are more realistic. Critical features exhibited by OPA, but not by other coarse-resolution global OGCMs, include (1) little upwelling of deep water to the surface and (2) a strong and narrow equatorial undercurrent. To demonstrate how the artifact of nutrient trapping is sensitive to model resolution, we present results from a sensitivity test that varied the horizontal eddy viscosity coefficient.

\section{Model Description}

In this study, the ocean's preindustrial state is simulated by implanting HAMOCC3 [Maier-Reimer, 1993] into a tracer-transport model driven by 3-D advective and diffusive fields predicted by the OGCM known as OPA [Delecluse et al., 1993]. Here we outline the important aspects of both the physical and biogeochemical models.

\subsection{Ocean General Circulation Model}

The OGCM used here was first developed a decade ago [Andrich, 1988]. Known as OPA, it has been modified for use as a regional [Blanke and Delecluse, 1993; Maes et al., 1997] and global-scale model [Marti, 1992; Delecluse et al., 1993; Madec and Imbard, 1996; Guilyardi and Madec, 1997]. OPA solves the primitive equations discretized on a C grid [Arakawa and Lamb, 1977] using the classical Boussinesq and rigid lid approximations. The horizontal mesh is curvilinear and orthog- 
onal, which ensures a second-order numerical accuracy [Marti et al., 1992]. The grid is distorted in the northern hemisphere so that the northern singularity is shifted to be over Asia. Horizontal grid spacing varies between $0.5^{\circ}$ and $2^{\circ}$ with its higher meridional resolution in the equatorial regions as a means to better resolve finescale features important in equatorial dynamics. The model has 30 vertical levels, among which 10 are located in the top $100 \mathrm{~m}$. The model is driven with the monthly mean climatology of wind stress [Hellerman and Rosenstein, 1983]. Heat fluxes and water fluxes are from Oberhüber [1988]. Additionally, temperature $T$ and salinity $S$ are restored at the surface toward climatological values [Levitus, 1982] using a damping time constant of 12 days.

Effects of nonresolved subgrid-scale movements on the large-scale circulation are parameterized by horizontal and vertical eddy diffusivities and viscosities. The horizontal eddy viscosity coefficient is imposed by the resolution. It is set to be equal to $4 \times 10^{4} \mathrm{~m}^{2} \mathrm{~s}^{-1} \mathrm{ev}-$ erywhere, except between $20^{\circ} \mathrm{S}$ and $20^{\circ} \mathrm{N}$, where it is gradually reduced to attain $2000 \mathrm{~m}^{2} \mathrm{~s}^{-1}$ at the equator. This reduction accounts for the ratio between the typical scale of the eddies and the horizontal spacing, which is smaller when near the equator than in higher latitudes. The horizontal eddy diffusivity coefficient is constant everywhere at $2000 \mathrm{~m}^{2} \mathrm{~s}^{-1}$. Vertical eddy diffusivity is not defined a priori. Instead, OPA includes a prognostic model of the turbulence based on the equations of the turbulent kinetic energy (TKE) model proposed by Gaspar et al. [1990] and adapted to OPA by Blanke and Delecluse [1993]. Thus OPA predicts turbulence and computes vertical eddy diffusivity and viscosity coefficients throughout the water column, i.e., within the mixed layer as well as below.

Because of OPA's relatively high horizontal and vertical resolution, it is run in a semidiagnostic mode; $T$ and $S$ are restored toward the climatological values of $L e v i$ tus [1982] not only at the surface (where this restoration is part of the boundary conditions) but also throughout most of the ocean. The restoring time constant used varies with depth from 50 days at $15 \mathrm{~m}$ (level 2 of OPA) to 1 year in the deep ocean. This approach is conceptually similar to the technique used by Toggweiler et al. [1989] in their "robust-diagnostic" version of the Geophysical Fluid Dynamics Laboratory (GFDL) model. Practically, though, there are major differences. In OPA, $T$ and $S$ are always restored in the first level, but below that, restoration is relaxed in four areas: (1) in the mixed layer, which is thus predicted prognostically, (2) in the equatorial regions, where small errors in observed density would lead to large errors in modelpredicted velocity fields [Fujio and Imasato, 1991], (3) in the high latitudes, where measurements are rare and biased toward summer values, and (4) along ocean-land boundaries to allow the model to reconstruct its own boundary currents.

Here we have used a tracer-transport (offline) version of OPA developed by Marti [1992]. This model uses monthly mean fields of advection, turbulence, $T$, and $S$, as predicted by the on-line model. Advective transport of tracers is computed according to the MPDATA scheme of Smolarkiewicz [1982, 1983], and Smolarkiewicz and Clark [1986]. Although expensive, this scheme is little diffusive and positive definite (that is, it avoids negative tracer concentrations).

\subsection{Carbon-Cycle Model}

The biogeochemical model HAMOCC3 [Maier-Reimer 1993] is coupled to OPA. Our first priority was to keep HAMOCC3 in its original state in order to allow a rigorous comparison of our results with results from MaierReimer [1993]. Although some minor adaptations were necessary, their effect is negligible as discussed below. We have made three changes in HAMOCC3 when we implemented it in OPA. First, the number of the simulated tracers has been reduced to 7 instead of the 20 included in the original model. This change was performed in order to reduce the computing cost of the combined OPA-HAMOCC3 model. Second, we computed the piston velocity using the formulation from Wanninkhof [1992] instead of using a constant value as in the work by Maier-Reimer [1993]. However, changes in the piston velocity do not affect the predicted distribution of phosphate. Third, we did not keep HAMOCC3's simple sedimentation model in OPA because a much longer integration would be necessary to equilibrate the model (tens of thousands of years instead of several thousand years).

For more efficient use, we included only the seven prognostic tracers necessary for the computation of the different biogenic fluxes of carbon: dissolved inorganic carbon (DIC), alkalinity, $\mathrm{O}_{2}$, calcite, $\mathrm{PO}_{4}^{3-}$, particulate organic carbon (POC), and dissolved silicate. These fluxes are divided into two components; the soft tissue pump and the hard tissue counterpump. The soft tissue pump is reduced, in the model, to the export production (EP), defined simply as the part of the primary production transported out of the euphotic zone. EP is computed as

$$
\mathrm{EP}=\mathrm{r}_{0} \mathrm{I} \frac{50}{\mathrm{Z}_{\mathrm{m}}} \frac{\mathrm{T}+2}{\mathrm{~T}+10}\left(\frac{\left[\mathrm{PO}_{4}^{3-}\right]}{\left[\mathrm{PO}_{4}^{3-}\right]+\mathrm{P}_{0}}\right)\left[\mathrm{PO}_{4}^{3-}\right]
$$

where $r_{0}$ is the maximum productivity rate, $I$ is a normalized light factor, $Z_{m}$ is the mixed layer depth, $T$ is temperature (degrees Celsius), and $P_{0}$ equals 0.02 $\mu \mathrm{mol} \mathrm{PL} L^{-1}$. Export production in nutrient-poor water is reduced by a simple Michaelis-Menten kinetics formula that depends on the local concentration of $\mathrm{PO}_{4}^{3-}$ 
[Dugdale, 1967]. In HAMOCC3, $\mathrm{PO}_{4}^{3-}$ is chosen as the limiting nutrient to avoid complexities associated with nitrogen cycling. The thickness of the euphotic zone is set to $50 \mathrm{~m}$ globally. The light factor $I$ is defined as the integration of the cosine of the solar angle over the day length, normalized to be comprised between 0 and 1 . Cloud cover is ignored in this computation. The maximum production efficiency $r_{0}$ is set to 0.25 /month as chosen by Maier-Reimer [1993] to adjust his model output to fit the observed surface phosphate distribution. The significance of the chosen value for $r_{0}$ is that, at most, $25 \%$ of local $\mathrm{PO}_{4}^{3-}$ can be removed each month from the surface by biological activity. The intensity of the hard tissue counterpump is deduced from export production via the rain ratio (organic $\mathrm{C} / \mathrm{CaCO}_{3}$ ratio) [Broecker and Peng, 1982]. This ratio depends on $T$ and the local concentration of dissolved silicate. The maximum value of the rain ratio is set in HAMOCC3 to 0.35 .

POC produced in the euphotic zone is exported instantaneously below $100 \mathrm{~m}$. The vertical profile of the POC flux is described according to a power law function $z^{-0.8}$ [Berger et al., 1987]. In HAMOCC3, denitrification is not considered. Thus the remineralization of the organic matter is restricted to regions with sufficient oxygen ( $\geq 1 \mu \mathrm{mol} \mathrm{L}^{-1}$ ). Otherwise, POC is preserved and transported by advection and diffusion.

At the sea surface, the ocean exchanges $\mathrm{CO}_{2}$ and $\mathrm{O}_{2}$ with the atmosphere. The net flux from air to sea $F$ is proportional to the difference between the partial pressure of the gas in air $P_{a}$ and that in surface seawater $P_{s}$ :

$$
F=k \alpha\left(P_{a}-P_{s}\right)
$$

where $\mathrm{k}$ is the gas transfer velocity (in $\mathrm{ms}^{-1}$ ), $\alpha$ is the gas solubility $\left(\mathrm{mol} \mathrm{m}^{-3} \mu \mathrm{atm}^{-1}\right)$. Instead of using a constant coefficient as did Maier-Reimer [1993], we computed the piston velocity of $\mathrm{CO}_{2}$ by using equation (8) from Wanninkhof [1992], a quadratic function of wind speed that includes a chemical enhancement at low wind speeds. We used a climatology of the monthly mean wind speeds and variances [Boutin and Etcheto, 1997] derived from special sensor microwave images $(\mathrm{SSM} / \mathrm{I})$ wind speeds [Went $z, 1992]$. The resulting gas exchange coefficient $K(K=k \alpha)$ for $\mathrm{CO}_{2}$ has been scaled so that its global mean value equals $0.061 \mathrm{~mol} \mathrm{~m}^{-2} \mu \mathrm{atm}^{-1} \mathrm{yr}^{-1}$ deduced from ${ }^{14} \mathrm{C}$ observations [Broecker et al., 1985]. The piston velocity of $\mathrm{O}_{2}$ is is computed according to the formulation from Liss and Merlivat [1986].

Besides the number of biogeochemical tracers and the formulation of the piston velocity, we made a third change in HAMOCC3. The simple parameterization of the sedimentation processes was eliminated because the long timescales associated with the sediments, on average, 45,000 years [Maier-Reimer, 1993], require very long model integrations that were beyond our means. However, fluxes between the ocean and the sediments as predicted by the original version of HAMOCC3 coupled to the LSG model are quite small, particularly for organic matter [Maier-Reimer, 1993]. Omitting these fluxes should not significantly alter modeled tracer distributions, especially that of phosphate in the upper equatorial Pacific Ocean.

\subsection{Initial Conditions and Model Integration}

Simulations are initialized with uniform distributions of tracers. $\mathrm{PO}_{4}^{3-}$ concentration is set to $2.1 \mu \mathrm{mol} \mathrm{L}-1$ , the observed global mean computed from Conkright et al. [1994]. Dissolved inorganic carbon is set to be $2350 \mu \mathrm{mol} \mathrm{L}^{-1}$. Total alkalinity is initialized to 2374 $\mu \mathrm{eq} \mathrm{kg}^{-1}$ [Takahashi et al., 1981]. Preindustrial atmospheric $\mathrm{pCO}_{2}$ is fixed at $278 \mathrm{ppm}$.

True steady state is reached when the globally and annually averaged air-to-sea flux of $\mathrm{CO}_{2}$ is zero. Since, in theory, this would require an infinitely long integration, we chose a small threshold value $\left(0.05 \mathrm{Pg} \mathrm{C} \mathrm{yr}^{-1}\right)$, below which the model was considered to be at equilibrium. To speed simulations, we used our recently developed technique, DEGINT [Aumont et al., 1998], which accelerated off-line simulations described here by a factor of 20. At equilibrium, the model's annual mean airto-sea $\mathrm{CO}_{2}$ flux, integrated globally, is $0.05 \mathrm{Pg} \mathrm{C} \mathrm{yr}^{-1}$.

\section{Results}

\subsection{Simulated Equatorial Pacific Dynamics}

Intense currents of limited meridional extent characterize equatorial dynamics in the Pacific. OPA's enhanced meridional resolution in this region improves the equatorial dynamics relative to other coarse-resolution global models. Below we discuss the main dynamic features of OPA that play a role in controlling the distribution of the biogeochemical tracers.

Figure 1 shows a section of the zonal velocity field along $150^{\circ} \mathrm{W}$. This section reveals that equatorial currents in OPA compare reasonably well with the observations of Wyrtki and Kilonsky [1984]. In particular, OPA is able to simulate a vigorous equatorial undercurrent (EUC) centered at the equator, whose speed exceeds $1 \mathrm{~m} \mathrm{~s}^{-1}$. The model maximum speed of $1.4 \mathrm{~m} \mathrm{~s}^{-1}$ at $140^{\circ} \mathrm{W}$ is close to that observed $\left(1.6 \mathrm{~m} \mathrm{~s}^{-1}\right)$ [Qiao and Weisberg, 1997]. Below the EUC, observations [Wyrtki and Kilonsky, 1984] show the presence of a geostrophic westward current, the equatorial intermediate current (EIC), whose speed can reach $0.15 \mathrm{~m} \mathrm{~s}^{-1}$. The model does not clearly reproduce the EIC. However, we know of no model that is able to reproduce such a current on an annual mean. OPA simulates a stronger EIC during boreal summer. In August, simulated speeds reach $0.13 \mathrm{~m} \mathrm{~s}^{-1}$ at $150^{\circ} \mathrm{W}$ and at a depth of about $500 \mathrm{~m}$, 
a)

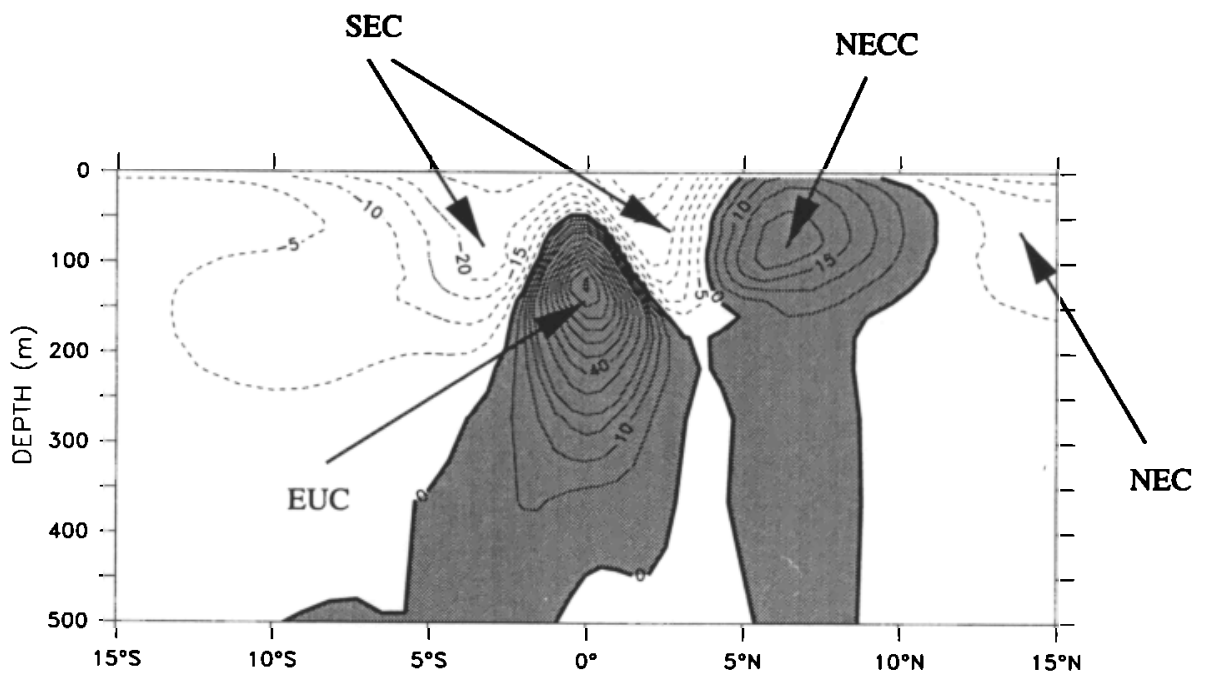

b)

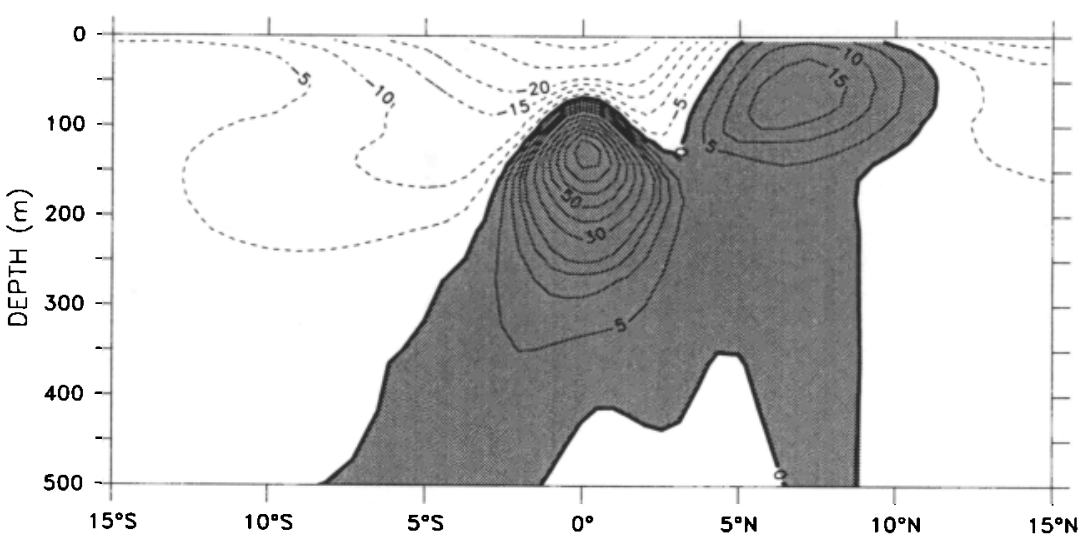

c)

LATITUDE

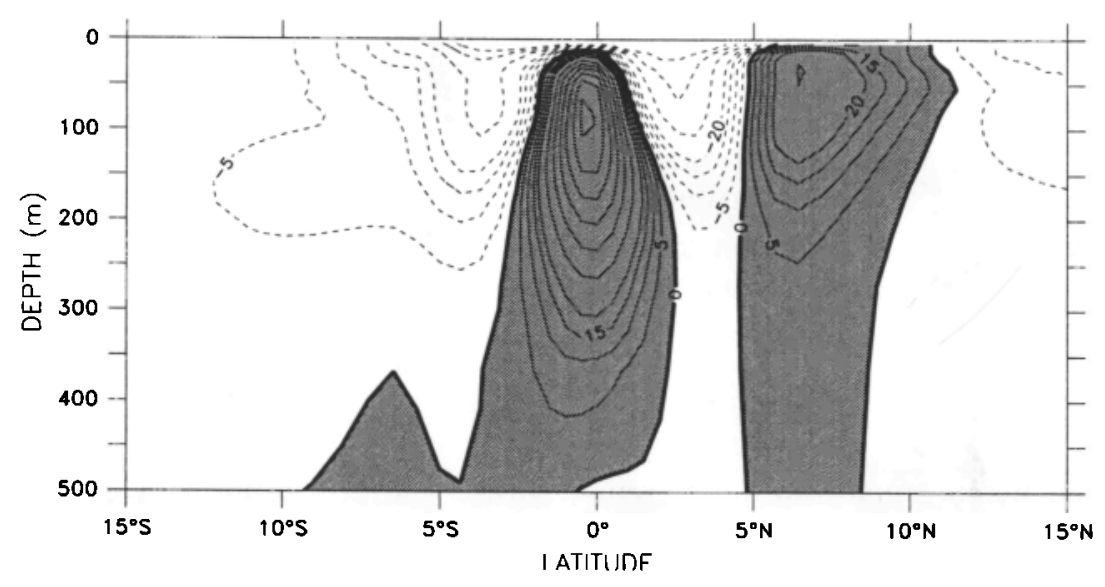

Figure 1. Annual mean distribution of zonal velocities $\left(\mathrm{cm} \mathrm{s}^{-1}\right)$ simulated by the Océan Parallélisé model (OPA) along $150^{\circ} \mathrm{W}$ in the near surface for (a) the standard simulation, (b) case HV, and (c) case CVD. Positive speeds indicate eastward flow.

which, incidentally, is of roughly the same magnitude as that offered by Wyrtki and Kilonsky [1984] as the annual mean.

At the surface, the south equatorial current (SEC), flowing westward, exhibits two distinct maxima, one north and one south of the equator (Figure 1). The SEC's double maximum is due to frictional effects of the EUC, which flows in the opposite direction and splits the SEC below the surface. The SEC is limited to the upper $200 \mathrm{~m}$ and is more rapid in the north. 


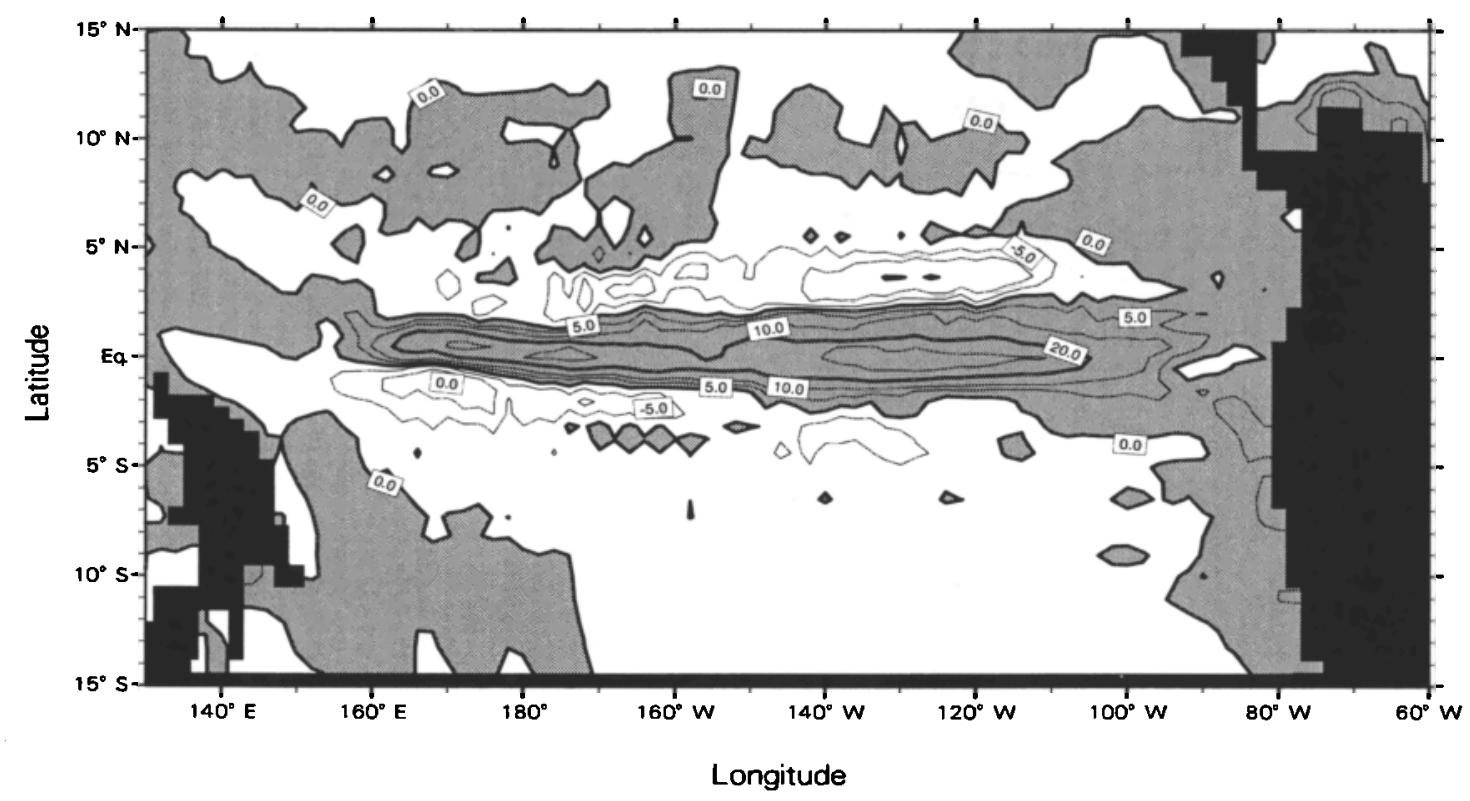

Figure 3. Modeled annual mean vertical velocities (in $10^{-6} \mathrm{~m} \mathrm{~s}^{-1}$ ) in the equatorial Pacific at $50 \mathrm{~m}$. Contour levels are drawn at $0,5,10,20$, and $30 \times 10^{-6} \mathrm{~m} \mathrm{~s}^{-1}$.

The associated vertical transport equals $38.6 \mathrm{~Sv}$ at 50 $\mathrm{m}$ for the area within $170^{\circ} \mathrm{E}$ to $100^{\circ} \mathrm{W}$ and $5^{\circ} \mathrm{S}$ to $5^{\circ} \mathrm{N}$. Observed values range from 37 to $51 \mathrm{~Sv}$ [Wyrtki, 1981]. The equatorial divergence in OPA exhibits large seasonal variability with distinct maxima in April-May and October-November, as in the observations [Poulain, 1993]. Along the Peruvian coast, northward wind stress forces coastal upwelling between $2^{\circ} \mathrm{S}$ and $15^{\circ} \mathrm{S}$. In this area, OPA transports $3.8 \mathrm{~Sv}$ upward toward the surface in agreement with the observed $4 \mathrm{~Sv}$ [Wyrtki, 1963].

To help diagnose tracer distributions in the equatorial Pacific, we determined the model's annual mean water transport budget for the upper eastern Pacific Ocean (Figure 4a). This region is exactly where coarseresolution models develop nutrient trapping [Najjar et al., 1992; Maier-Reimer, 1993]. Laterally, the region is defined as that between $130^{\circ} \mathrm{W}$ and $80^{\circ} \mathrm{W}$ and between $5^{\circ} \mathrm{S}$ and $5^{\circ} \mathrm{N}$. Vertically, we further divided this region into three zones: (1) the surface euphotic zone located in the top $50 \mathrm{~m}$; (2) the intermediate zone between 50 and $423 \mathrm{~m}$, which is affected by the EUC; and (3) the deep zone $(423-870 \mathrm{~m})$, where nutrient trapping is at its maximum. The equatorial divergence upwells 23.1 $\mathrm{Sv}$ of middepth waters into the productive surface zone. More than half of that is transported westward by the SEC out of the region defined above; the rest escapes meridionnally.

The divergence is fed by water from the core of the EUC, which itself advects $33.3 \mathrm{~Sv}$ into the domain. The water flux at $130^{\circ} \mathrm{W}$ is substantially less $(25.1 \mathrm{~Sv})$ because in that region, the middepth box also includes the lower part of the westward flowing SEC. At $80^{\circ} \mathrm{W}$, the EUC nearly vanishes owing to continuous upwelling and subsequent poleward divergence near the surface. The meridional geostrophic loss of water is small (1.1 Sv). Across the EUC, there is no input of water from the deep ocean. The deepest box correspond to the domain that should be affected by the EIC. Associated transport is $1.5 \mathrm{~Sv}$, about 1 order of magnitude too small relative to annual mean estimates of Wyrtki and Kilonsky [1984].

\subsection{Simulated $\mathbf{P O}_{4}^{3-}$}

Figure 5 shows the annually averaged distribution of surface $\mathrm{PO}_{4}^{3-}$ as taken from the top $5 \mathrm{~m}$ in the $\mathrm{Na}$ tional Oceanographic Data Center (NODC) world atlas [Conkright et al., 1994] and the top $10 \mathrm{~m}$ simulated by OPA. Maximum simulated $\mathrm{PO}_{4}^{3-}$ concentrations are found in the Peruvian upwelling, where they exceed 1 $\mu \mathrm{mol} \mathrm{L}^{-1}$, in agreement with observations. Upwelled waters are transported northward and westward. Owing to the westward transport both in the model and observations, the Peruvian upwelling appears to feed the divergence with substantial $\mathrm{PO}_{4}^{3-}$. However, it requires about 10 months for the water to move from the Peruvian coast to where the divergence is at its maximum $\left(120^{\circ} \mathrm{W}\right)$, as determined from the modeled zonal velocity of $10 \mathrm{~cm} \mathrm{~s}^{-1}$ in this region. Thus most of the upwelled $\mathrm{PO}_{4}^{3-}$ is consumed in the model by biota before it reaches the divergence, because in that region modeled production efficiency is close to its maximum $(0.25 /$ month $)$. Further west of coastal upwelling, at 




Figure 3. Modeled annual mean vertical velocities (in $10^{-6} \mathrm{~m} \mathrm{~s}^{-1}$ ) in the equatorial Pacific at $50 \mathrm{~m}$. Contour levels are drawn at $0,5,10,20$, and $30 \times 10^{-6} \mathrm{~m} \mathrm{~s}^{-1}$.

The associated vertical transport equals $38.6 \mathrm{~Sv}$ at 50 $\mathrm{m}$ for the area within $170^{\circ} \mathrm{E}$ to $100^{\circ} \mathrm{W}$ and $5^{\circ} \mathrm{S}$ to $5^{\circ} \mathrm{N}$. Observed values range from 37 to $51 \mathrm{~Sv}$ [Wyrtki, 1981]. The equatorial divergence in OPA exhibits large seasonal variability with distinct maxima in April-May and October-November, as in the observations [Poulain, 1993]. Along the Peruvian coast, northward wind stress forces coastal upwelling between $2^{\circ} \mathrm{S}$ and $15^{\circ} \mathrm{S}$. In this area, OPA transports $3.8 \mathrm{~Sv}$ upward toward the surface in agreement with the observed $4 \mathrm{~Sv}$ [Wyrtki, 1963].

To help diagnose tracer distributions in the equatorial Pacific, we determined the model's annual mean water transport budget for the upper eastern Pacific Ocean (Figure 4a). This region is exactly where coarseresolution models develop nutrient trapping [Najjar et al., 1992; Maier-Reimer, 1993]. Laterally, the region is defined as that between $130^{\circ} \mathrm{W}$ and $80^{\circ} \mathrm{W}$ and between $5^{\circ} \mathrm{S}$ and $5^{\circ} \mathrm{N}$. Vertically, we further divided this region into three zones: (1) the surface euphotic zone located in the top $50 \mathrm{~m}$; (2) the intermediate zone between 50 and $423 \mathrm{~m}$, which is affected by the EUC; and (3) the deep zone $(423-870 \mathrm{~m})$, where nutrient trapping is at its maximum. The equatorial divergence upwells 23.1 $\mathrm{Sv}$ of middepth waters into the productive surface zone. More than half of that is transported westward by the SEC out of the region defined above; the rest escapes meridionnally.

The divergence is fed by water from the core of the EUC, which itself advects $33.3 \mathrm{~Sv}$ into the domain. The water flux at $130^{\circ} \mathrm{W}$ is substantially less $(25.1 \mathrm{~Sv})$ because in that region, the middepth box also includes the lower part of the westward flowing SEC. At $80^{\circ} \mathrm{W}$, the EUC nearly vanishes owing to continuous upwelling and subsequent poleward divergence near the surface. The meridional geostrophic loss of water is small (1.1 Sv). Across the EUC, there is no input of water from the deep ocean. The deepest box correspond to the domain that should be affected by the EIC. Associated transport is $1.5 \mathrm{~Sv}$, about 1 order of magnitude too small relative to annual mean estimates of Wyrtki and Kilonsky [1984].

\subsection{Simulated $\mathbf{P O}_{4}^{3-}$}

Figure 5 shows the annually averaged distribution of surface $\mathrm{PO}_{4}^{3-}$ as taken from the top $5 \mathrm{~m}$ in the $\mathrm{Na}$ tional Oceanographic Data Center (NODC) world atlas [Conkright et al., 1994] and the top $10 \mathrm{~m}$ simulated by OPA. Maximum simulated $\mathrm{PO}_{4}^{3-}$ concentrations are found in the Peruvian upwelling, where they exceed 1 $\mu \mathrm{mol} \mathrm{L}{ }^{-1}$, in agreement with observations. Upwelled waters are transported northward and westward. Owing to the westward transport both in the model and observations, the Peruvian upwelling appears to feed the divergence with substantial $\mathrm{PO}_{4}^{3-}$. However, it requires about 10 months for the water to move from the Peruvian coast to where the divergence is at its maximum $\left(120^{\circ} \mathrm{W}\right)$, as determined from the modeled zonal velocity of $10 \mathrm{~cm} \mathrm{~s}^{-1}$ in this region. Thus most of the upwelled $\mathrm{PO}_{4}^{3-}$ is consumed in the model by biota before it reaches the divergence, because in that region modeled production efficiency is close to its maximum $(0.25 /$ month $)$. Further west of coastal upwelling, at 
a)

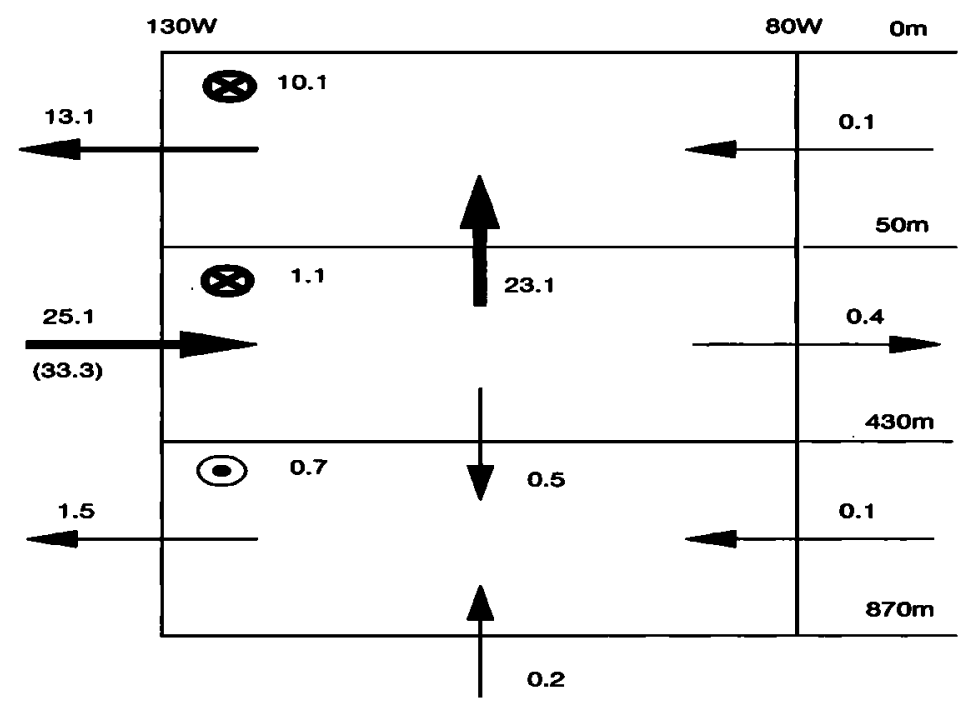

b)

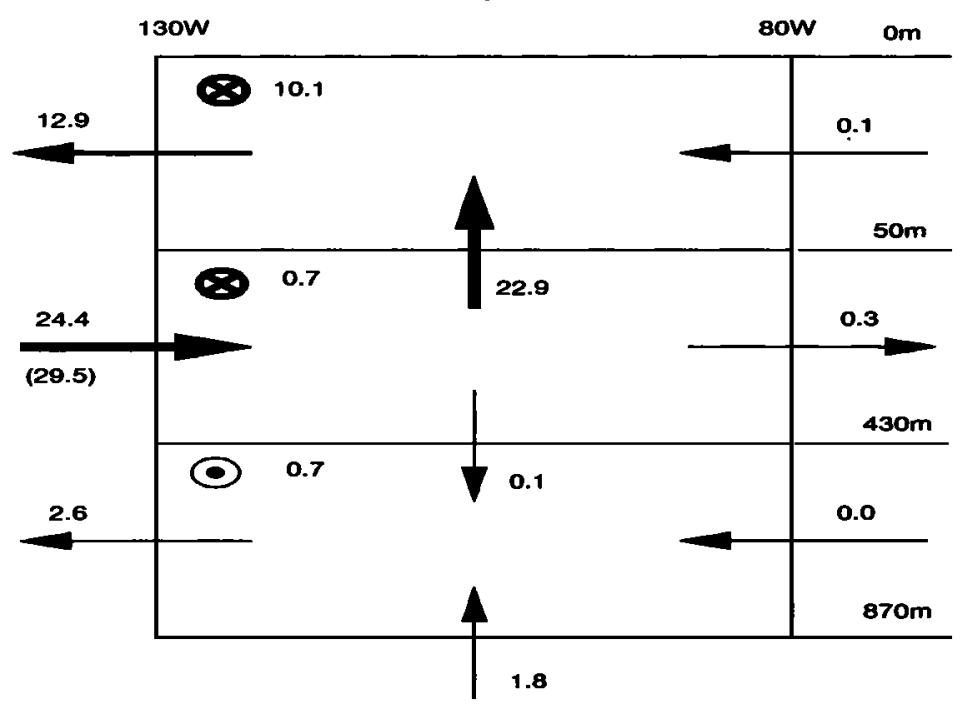

C)

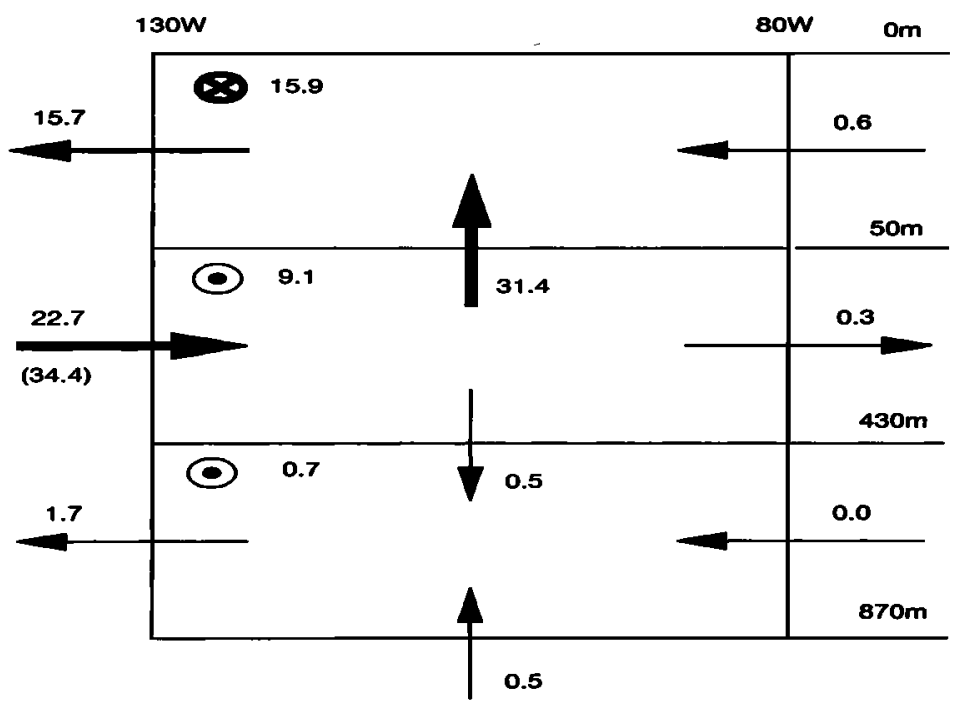

Figure 4. Water mass budget in the upper eastern equatorial Pacific Ocean for (a) the standard simulation in OPA, (b) case $\mathrm{HV}$, and (c) case CVD. Region limits are $80^{\circ} \mathrm{W}-130^{\circ} \mathrm{W}, 4.7^{\circ} \mathrm{S}-$ $4.7^{\circ} \mathrm{N}$, and $0-870 \mathrm{~m}$. Circled crosses indicate transport out of the domain; circled dots represent transport into the domain. Numbers in parentheses denote the transport associated with the equatorial undercurrent (EUC) only. All transports are in sverdrups $\left(1 \mathrm{~Sv}=110^{6} \mathrm{~m}^{3} \mathrm{~s}^{-1}\right)$. 
a)

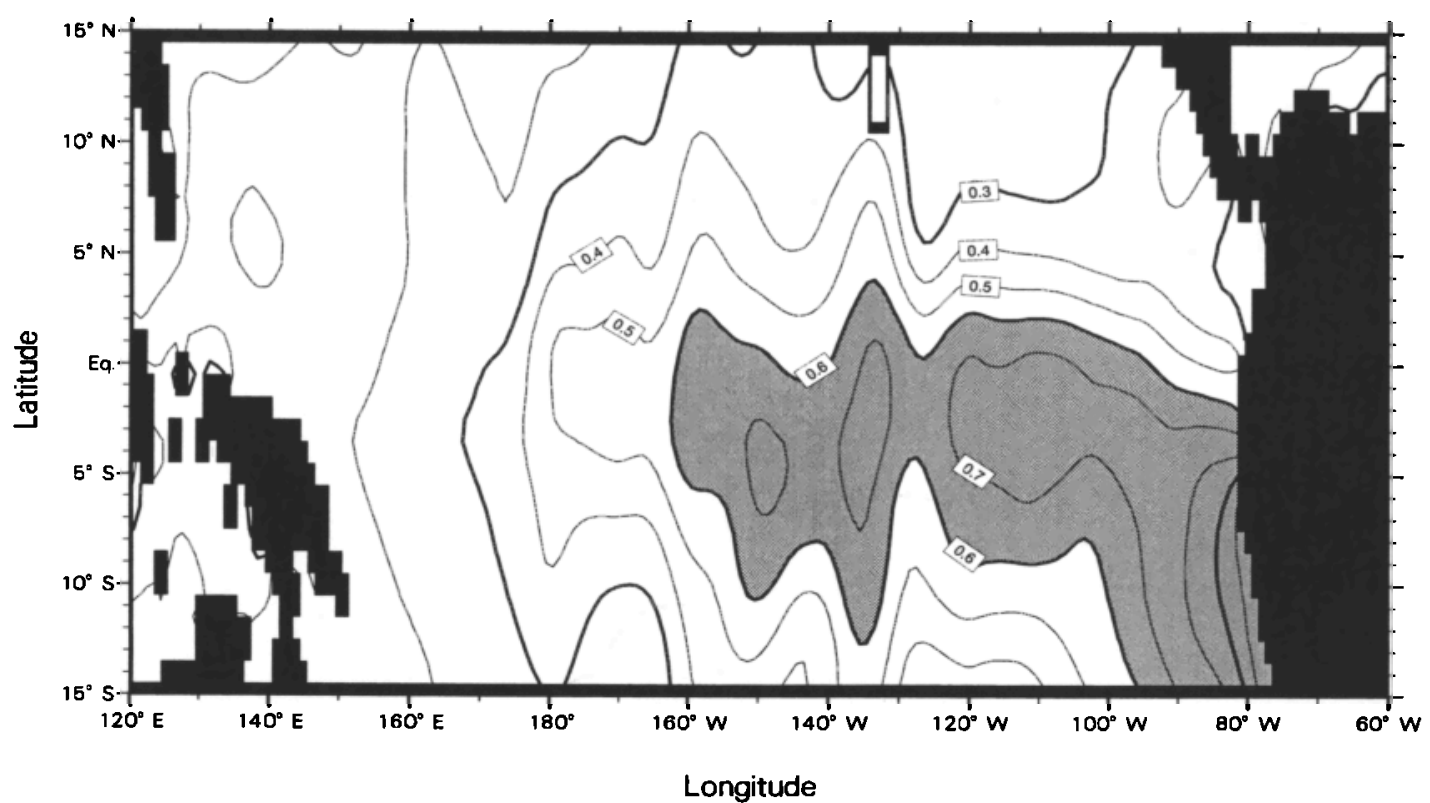

b)

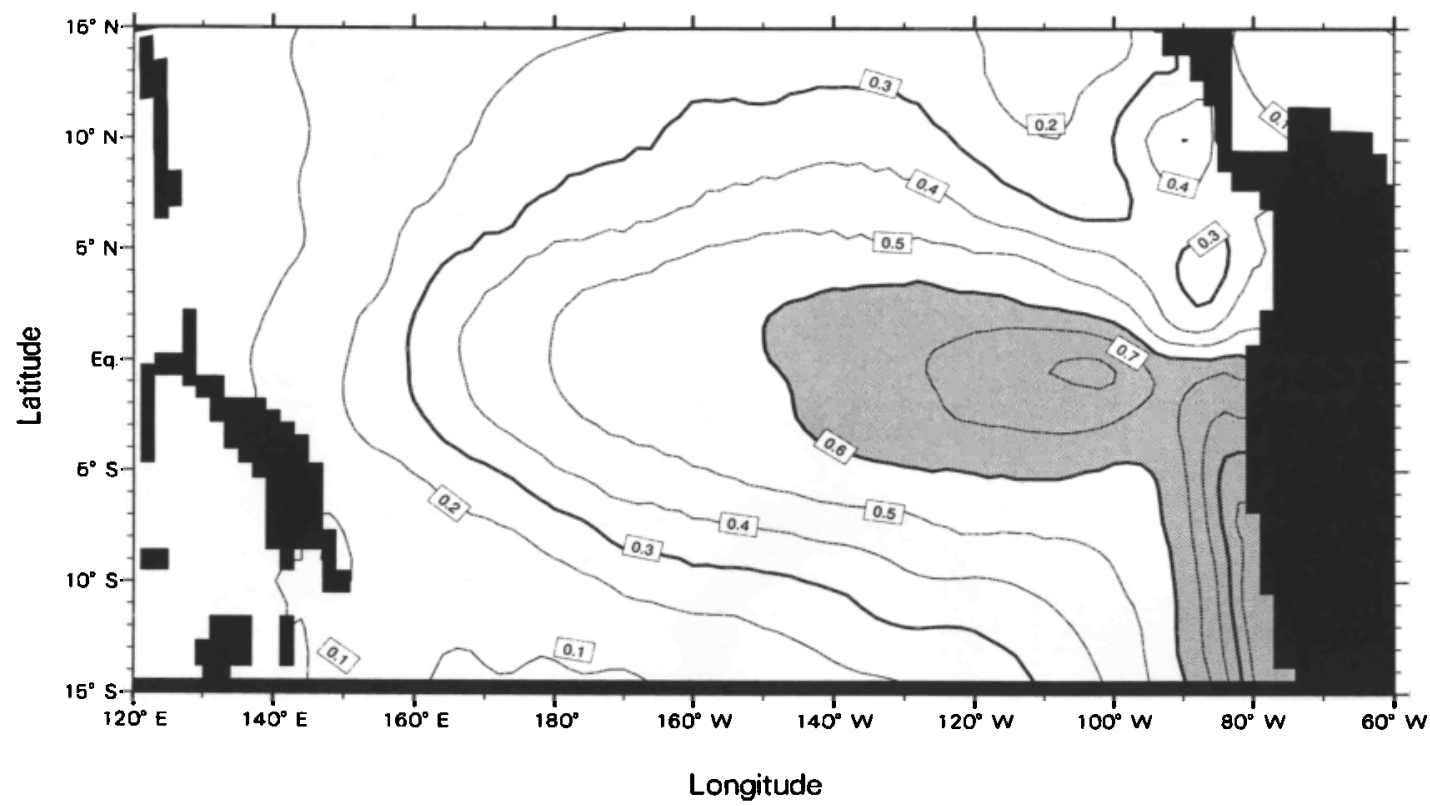

Figure 5. Annual mean distribution of $\mathrm{PO}_{4}^{3-}(\mu \mathrm{mol} \mathrm{L}-1)$ at the sea surface in the equatorial Pacific, showing (a) observations from Conkright et al. [1994] and (b) output from OPA. Contours are given for every $0.1 \mu \mathrm{mol} \mathrm{L}{ }^{-1}$.

$105^{\circ} \mathrm{W}$, the model simulates a second maximum. Also located there is the model's local maximum in vertical velocity.

Both modeled and observed distributions of $\mathrm{PO}_{4}^{3-}$ are asymmetrical with respect to the equator. East of $150^{\circ} \mathrm{W}$, maximum surface concentrations are located mainly in the southern hemisphere. Lower values in the northern hemisphere, noticed previously for nitrate [Toggwealer et al., 1991], are due to the NECC, which brings in waters with lower nutrient concentrations from the western Pacific [Toggweiler and Carson, 1995].

Figure 6 shows sections of observed $\mathrm{PO}_{4}^{3-}$ and modeled total phosphorus concentrations along the equator in the Pacific ocean. In the model, we consider total phosphorus ( $\left.\mathrm{PO}_{4}^{3-}+\mathrm{POP}\right)$ because the model's lack of oxygen in the eastern Pacific ocean produces a large pool of unremineralized POC [Maıer-Reımer, 1993, Figures $14 \mathrm{a}$ and $14 \mathrm{~b}]$. Total $P$ can be defined as that $P$ 
a)

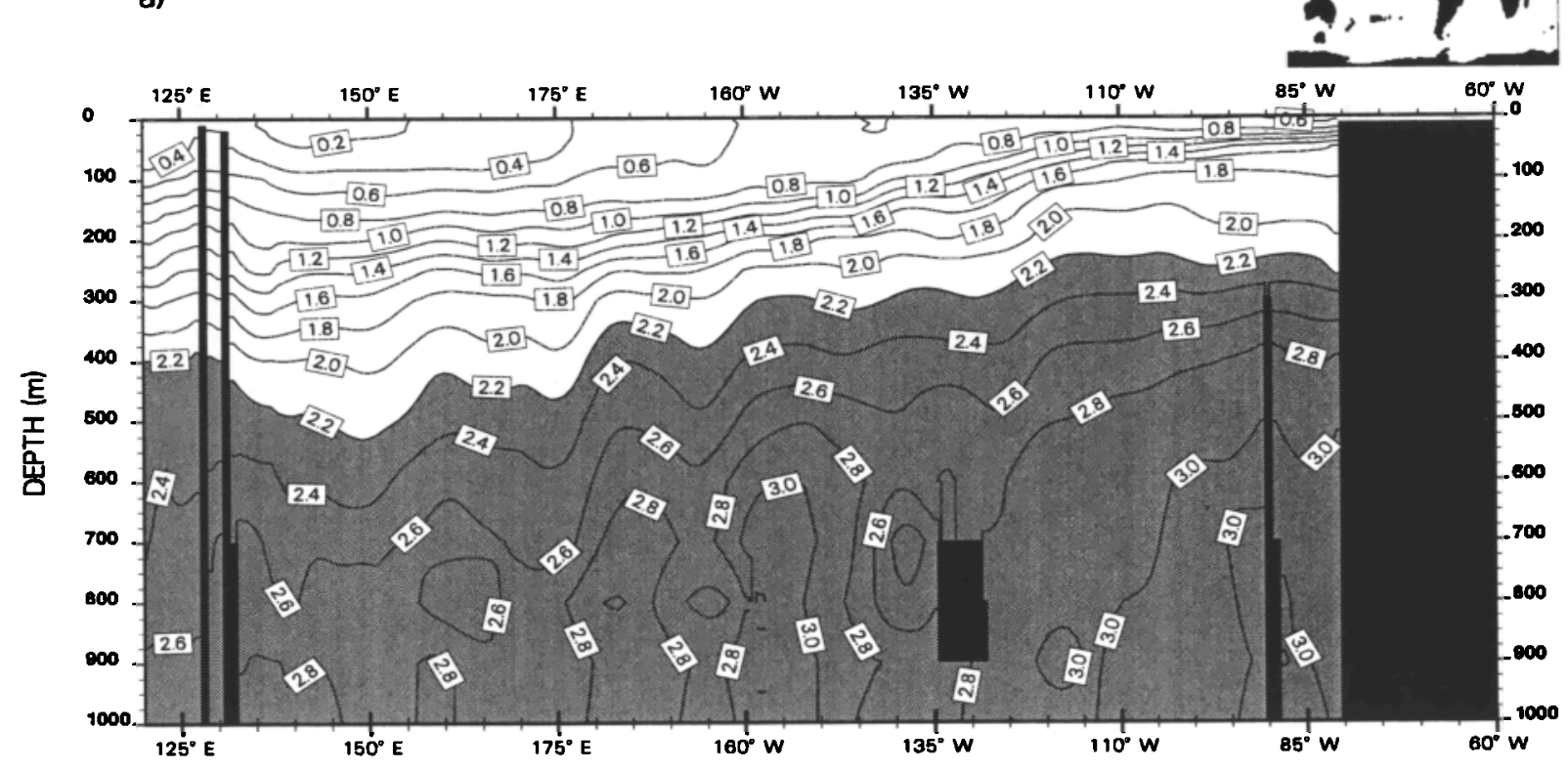

b)

LONGITUDE

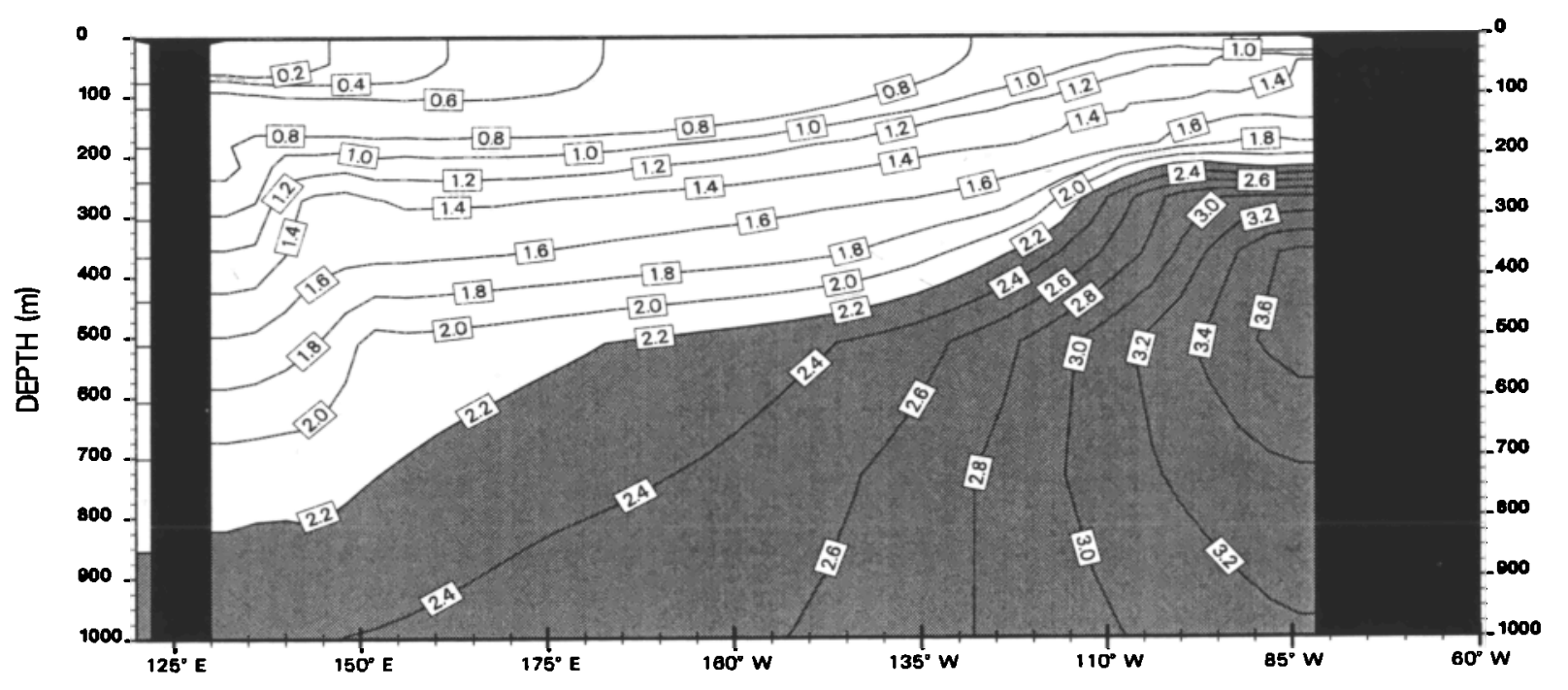

LONGITUDE

Figure 6. Annual mean distribution of $\mathrm{PO}_{4}^{3-}(\mu \mathrm{mol} \mathrm{L}-1)$ in the upper $1000 \mathrm{~m}$ of the water column along the equator in the Pacific, showing (a) observations from Conkright et al. [1994], (b) standard case, (c) case HV, and (d) case CVD. For the model, total phosphorus is considered instead of $\mathrm{PO}_{4}^{3-}$ alone, as explained in the text. Black areas in Figure 6a correspond to the bathymetry but also to regions where data are unavailable.

which is potentially available for biological consumption. To infer the sensitivity of the total $\mathbf{P}$ distribution to this lack of oxygen, we made a test (not shown) with the model where remineralization occurs even after waters become anoxic. The total $\mathbf{P}$ distribution is nearly unchanged. Considering previous modeling efforts, it is remarkable that OPA-HAMOCC3 exhibits only a minor case of nutrient trapping. At $800 \mathrm{~m}$, the model's maximum concentration is $3.4 \mu \mathrm{mol} \mathrm{L}^{-1}$ , about $0.4 \mu \mathrm{mol} \mathrm{L}^{-1}$ higher than in the obervations. 
c)

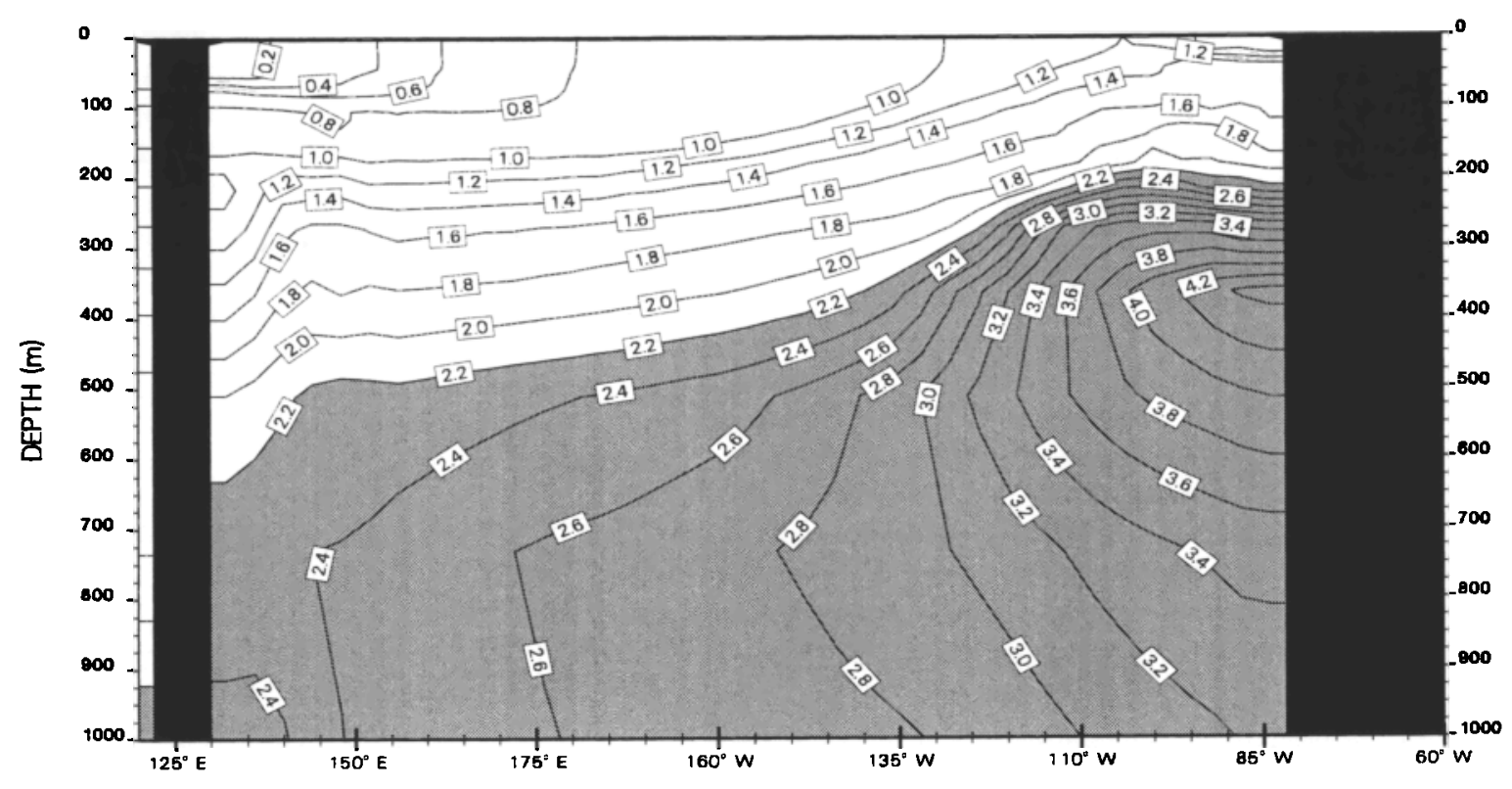

LONGITUDE

d)

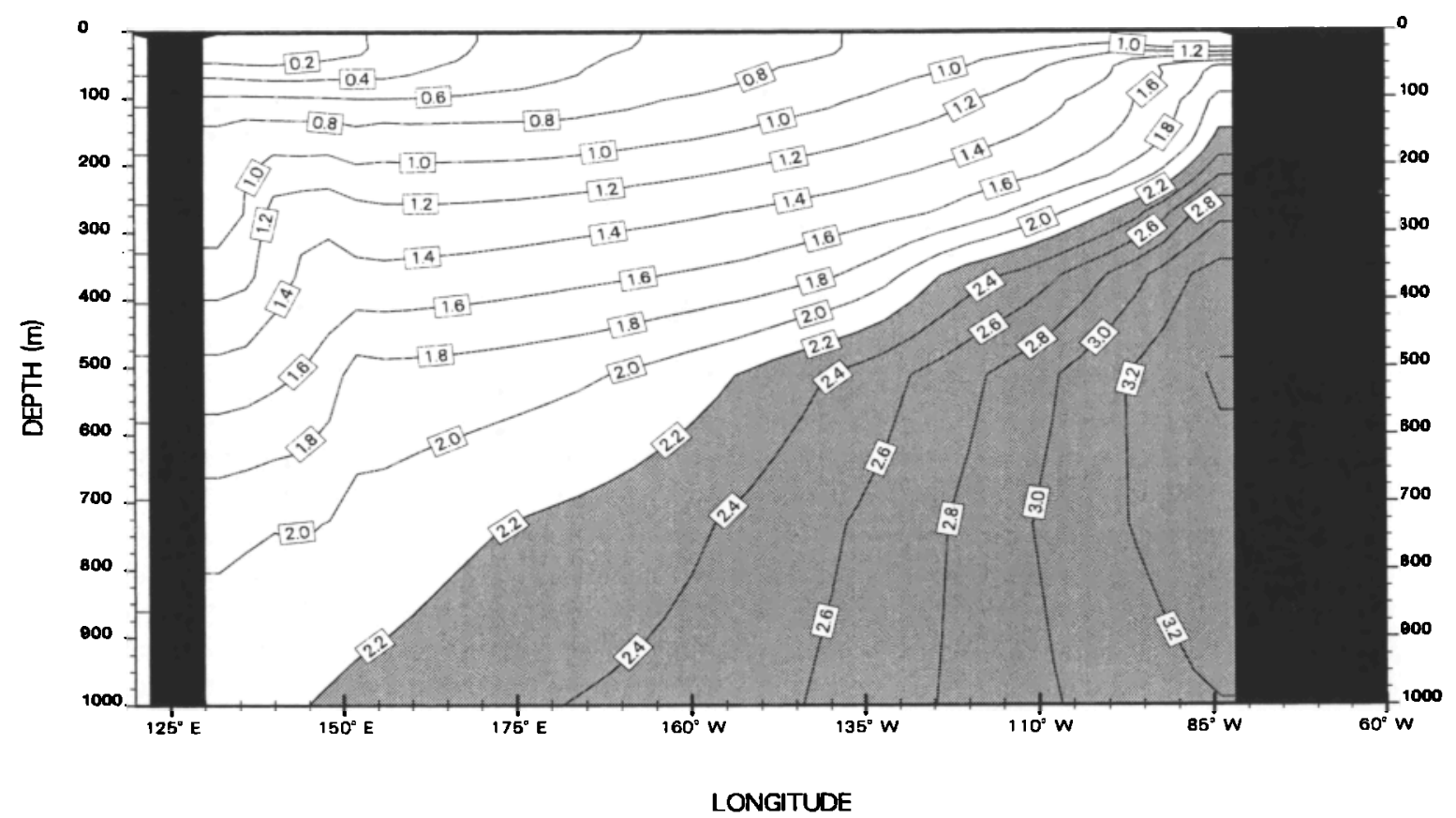

Figure 6. (continued)

In comparison, the difference between modeled and observed concentrations exceeds $2.5 \mu \mathrm{mol} \mathrm{L}^{-1}$ in the work of Maier-Reimer [1993] and $1.5 \mu \mathrm{mol} \mathrm{L}^{-1}$ in the work of Najjar et al. [1992] at about the same depth. Since we use the same biogeochemical model as Maier-Reimer [1993], the improvement must be due to the different modeled circulation, particularly the different equato- rial dynamics. Causes of the improvement are examined below.

On its way eastward, the EUC is progressively enriched in $\mathrm{PO}_{4}^{3-}$ owing to export production from above. Originating in the far western Pacific Ocean, the EUC advects water having lower $\mathrm{PO}_{4}^{3-}$ concentrations into waters enriched in $\mathrm{PO}_{4}^{3-}$. Thus the EUC dilutes mid- 
depth waters that are brought to the surface by the divergence. As a consequence, the undercurrent is largely responsible for the sharp vertical gradient between 50 and $400 \mathrm{~m}$. The model's vertical gradient is weaker than observed, in part because the simulated EUC extends too deeply; that is, there is no EIC (see section 3.1). The model's poorly constrained remineralization scheme may also be somewhat responsible.

\section{3. $\mathrm{PO}_{4}^{3-}$ Budget}

To better understand why OPA exhibits little nutrient trapping, we constructed a phosphorus budget for the eastern equatorial Pacific (Figure 7a), dividing the region into the same three vertical layers as for the water mass budget (Figure 4). The EUC's role in this budget seems a paradox, as noted by Toggweiler and Carson [1995]. On one hand, the EUC is the major supplier of water and nutrients, advecting $34.3 \mathrm{kmolP} \mathrm{s}^{-1}$ into the upwelling system; on the other hand, the EUC dilutes nutrient concentrations of the waters upwelled toward the surface because its source is in the west, where $\mathrm{PO}_{4}^{3-}$ concentrations are, on average, $0.6 \mu \mathrm{mol} \mathrm{L}^{-1}$ lower than in the intermediate zone of the eastern equatorial Pacific.

Of the $42.1 \mathrm{kmol} \mathrm{P} \mathrm{s}^{-1}$ brought into the intermediate box by the EUC and export production from above, three fourths $\left(31.5 \mathrm{kmol} \mathrm{P} \mathrm{s}^{-1}\right)$ is upwelled into the productive zone. The remaining one fourth $(8.9$ $\mathrm{kmol} \mathrm{P} \mathrm{s}{ }^{-1}$ ) is advected latitudinally; $75 \%$ of that is lost by transport to the south. Some of this southward outflow eventually feeds into the Peru upwelling. Such is consistent with observations that indicate that waters upwelled off the coast of Peru originate from the lower part of the EUC [Wyrtki, 1963; Lukas, 1986; Toggweiler et al., 1991].

In the euphotic zone, about $2 / 3\left(19.9 \mathrm{kmol} \mathrm{P} \mathrm{s}^{-1}\right)$ of the $\mathrm{PO}_{4}^{3-}$ upwelled from the midlayer box exits the surface box laterally. Lateral loss is divided nearly equally between transport by the westward flowing SEC and meridional transport across the southern and northern edges. Toggweiler and Carson [1995] found a somewhat lower amount, about $50 \%$, leaving the surface box by lateral export, after summing transport of nitrate $(30 \%)$ and organic matter (20\%). Concerning the remaining one third $\left(11.7 \mathrm{kmol} \mathrm{P} \mathrm{s}^{-1}\right)$ of the phosphorus that leaves the euphotic zone in OPA-HAMOCC3, it is exported into deeper layers by sinking particles. The mean POC export rate was estimated to be 3 $\mathrm{mmol} \mathrm{C} \mathrm{m}{ }^{-2} \mathrm{~d}^{-1}$ by Murray et al. [1994] at $120 \mathrm{~m}$ along $140^{\circ} \mathrm{W}$, using the ${ }^{234} \mathrm{Th}$ method [Buesseler et al., 1992]. At the same depth and location, the modeled export production is $6.6 \mathrm{mmol} \mathrm{C} \mathrm{m}^{-2} \mathrm{~d}^{-1}$, which is more than 2 times higher. However, fluxes of organic matter in this region exhibit a large temporal variability, and data-based estimates are relatively uncertain. POC export estimates at the same location can be significantly higher according to Murray et al. [1996], who used information from both ${ }^{234} \mathrm{Th}$ and drifting sediment traps. Their export estimates range from 2 and $30 \mathrm{mmol} \mathrm{C} \mathrm{m}^{-2} \mathrm{~d}^{-1}$ during September 1992, a period characteristic of non-El Niño conditions.

Fluxes into and out of the deep box are much smaller. In OPA, there is little input of phosphorus from the deep ocean. None of that makes it across OPA's strong EUC. Such minimal upwelling is remarkable for coarseresolution global models but not for high-resolution regional models [Toggweiler and Carson, 1995]. This lack of upwelled deep phosphorus was expected in view of the water mass budget. Phosphorus entering the deep box by transport or export production leaves it through the deep box's western limit.

Observational and modeling studies [Tsuchiya, 1981; Toggweiler et al., 1991; Blanke and Raynaud, 1997] have shown that most of the water entering into the equatorial Pacific's source zone for the EUC derives from the southern hemisphere. To better determine its source in OPA, we analyzed nutrient transport in the area between $5^{\circ} \mathrm{S}$ and $5^{\circ} \mathrm{N}$ and $130^{\circ} \mathrm{E}$ and $150^{\circ} \mathrm{E}$ (not shown), where the EUC originates. We found that of the 16 $\mathrm{kmol} P$ entering that box every second, roughly $70 \%$ derives from the southern hemisphere, mostly transported by the New Guinea Undercurrent (NGUC).

\subsection{Sensitivity Tests}

OPA has two peculiarities that have the potential to contribute to its improved ability to match observed phosphate. First, OPA's $0.5^{\circ}$ meridional resolution near the equator is enhanced relative to the roughly $4^{\circ}$ resolution used by other global-scale, coarse-resolution models. Second is OPA's prognostic parameterization of vertical turbulence (TKE) throughout the water column. OPA's semidiagnostic forcing is unimportant here because OPA is completely prognostic in the equatorial region. The combination of higher resolution and the TKE model of vertical turbulence are together responsible for the absence of substantial nutrient trapping in OPA. To determine the contribution of each factor, we performed two sensitivity tests with the on-line version of OPA (Table 1).

For the first test, we increased the equatorial horizontal viscosity coefficients used in OPA $\left(2000 \mathrm{~m}^{2} \mathrm{~s}^{-1}\right)$ by a factor of 20 to their extratropical value $(40,000$ $\left.\mathrm{m}^{2} \mathrm{~s}^{-1}\right)$. We term this as case HV. Such an experiment is motivated by the use of large horizontal eddy viscosity coefficients in coarse-resolution models, as required to avoid numerical problems (i.e., to simulate smooth solutions). Owing to such high viscosity, simulated horizontal speeds in coarse-resolution models are often underestimated, particularly the speed of the EUC [Toggweiler et al., 1989]. However, our case HV is not exactly equiv- 
a)

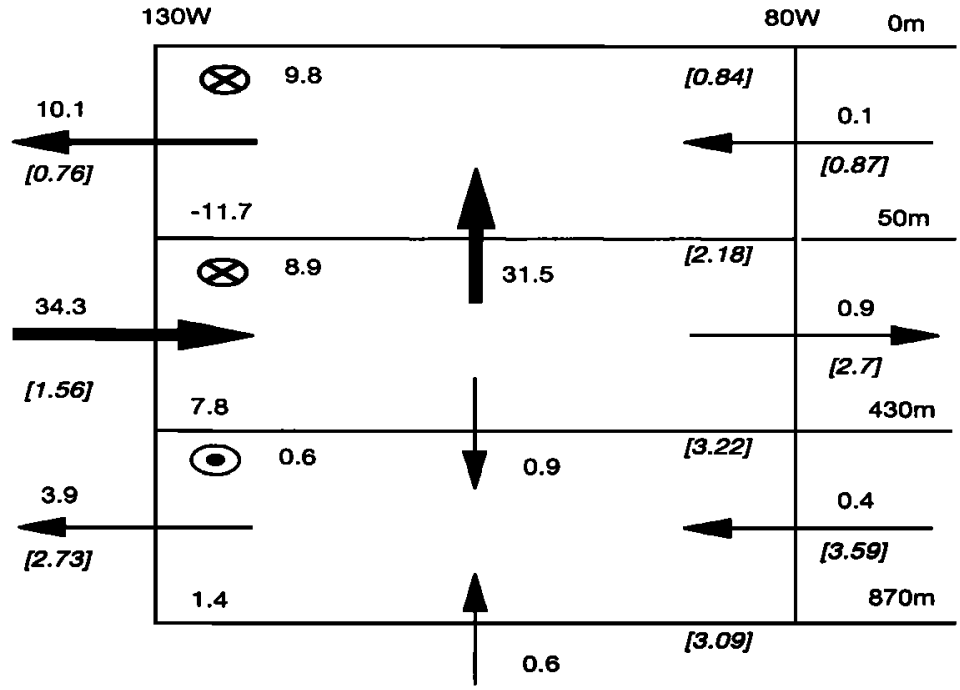

b)

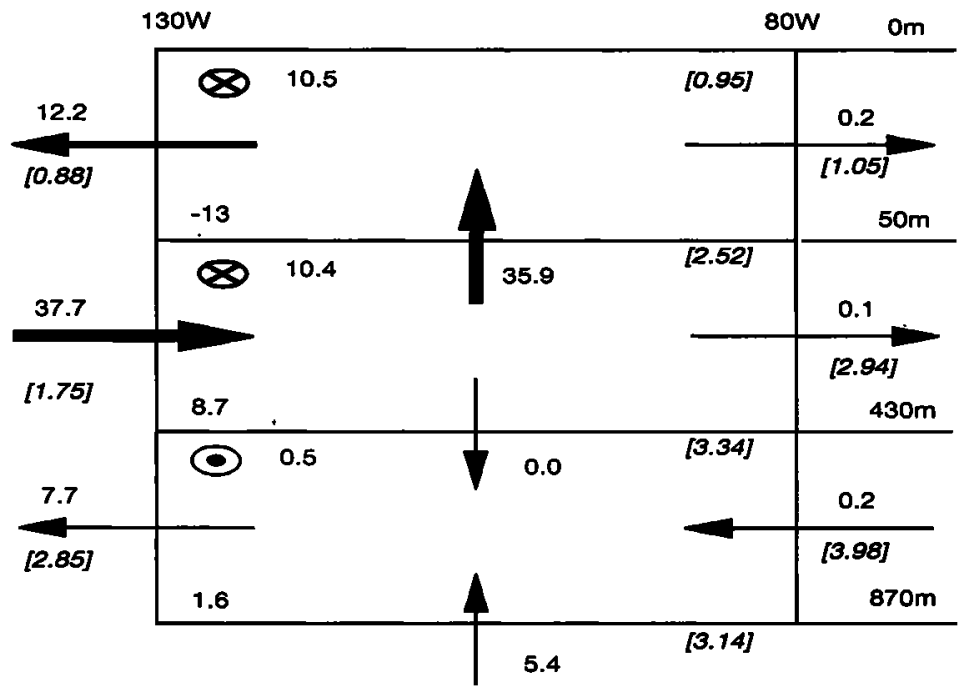

c)

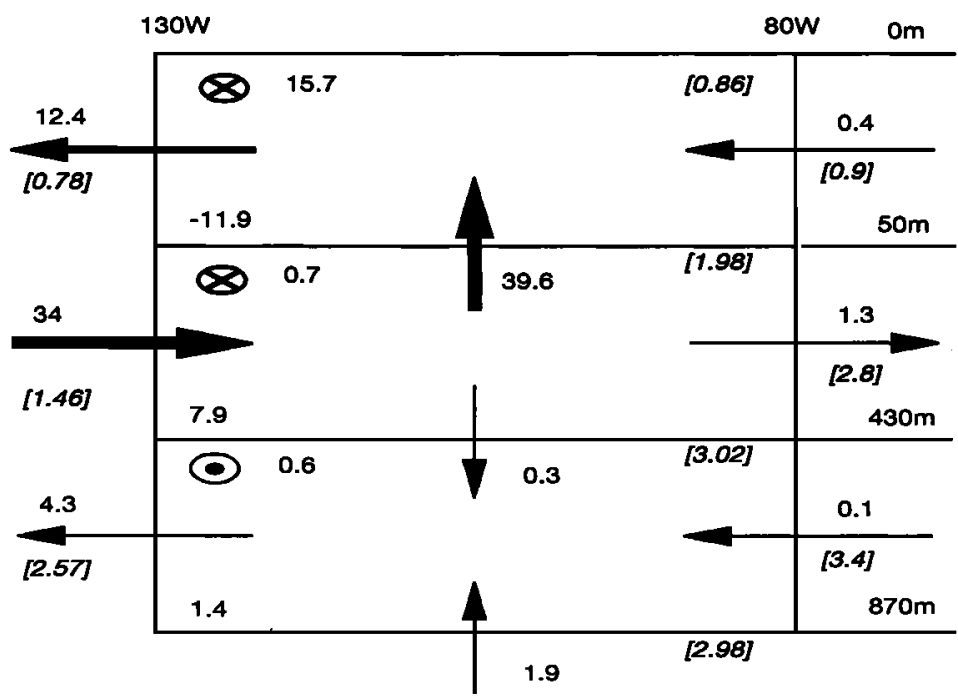

Figure 7. Annual mean total phosphorus budget for the upper $870 \mathrm{~m}$ in the eastern equatorial Pacific Ocean for (a) the standard case, (b) case HV, and (c) case CVD. Fluxes units are $\mathrm{kmol} \mathrm{P} \mathrm{s}^{-1}$. Circled crosses (dots) represent meridional outfluxes (influxes). The number at the bottom left of each box represents the net flux related to biological activity. Italicized, bracketed numbers are total phosphorus concentrations averaged over each box $\left(\mu \mathrm{mol} \mathrm{L}{ }^{-1}\right)$. 
Table 1. Summary of the Dynamic Experiments.

\begin{tabular}{lcc}
\hline Experiment & $\begin{array}{c}\text { Vertical Diffusion, } \\
\mathrm{cm}^{2} \mathrm{~s}^{-1}\end{array}$ & $\begin{array}{c}\text { Horizontal Viscosity, } \\
\mathbf{m}^{2} \mathbf{s}^{-1}\end{array}$ \\
\hline Standard run & TKE & $2,000-40,000$ \\
HV & TKE & 40,000 \\
CVD & 0.3 & $2,000-40,000$ \\
\hline
\end{tabular}

TKE denotes the pronostic model of vertical tubulence proposed by Gaspar et al. [1990] and by Blanke and Delecluse [1993]. First and second values for horizontal viscosity coefficients are their values at the equator and outside the tropical regions, respectively.

alent to a decrease of the resolution. Much poorer resolution alters equatorial dynamics simply because the grid size is too large to correctly resolve, meridionally, the fine-scale equatorial currents such as the EUC or the NECC. Thus our case HV infers only some of the changes due to using a coarser resolution; a full coarseresolution model would perform more poorly.

In the second sensitivity test, OPA was run without the prognostic parameterization of vertical turbulence. Instead, one vertical diffusion coefficient is defined a priori as equal to $0.3 \mathrm{~cm}^{2} \mathrm{~s}^{-1}$ everywhere within the ocean. We term this as case CVD. Both sensitivity tests were performed with the on-line version of OPA. Resulting monthly averaged dynamic fields were used to drive the off-line version of the model, as in our standard run.

Figure 1 includes sections of the zonal velocity field for both sensitivity tests. In case HV, zonal currents, especially the EUC and the NECC, are, on average, slower than in the standard case. Along $150^{\circ} \mathrm{W}$, the maximum speed of the EUC is about $0.85 \mathrm{~m} \mathrm{~s}^{-1}$ instead of about $1 \mathrm{~m} \mathrm{~s}^{-1}$ in the standard case. A decrease in the intensity of the EUC was also found in a similar experiment by Maes et al. [1997]. Consequently, the predicted SEC does not present the two distinct maxima both observed and simulated in the standard case. Instead, the SEC reaches its maximum speed right at the equator. In case CVD, abandon of the TKE scheme produces a much more intense SEC. Weaker near-surface vertical mixing decreases the Ekman layer depth and thus the vertical dissipation. Consequently, horizontal near-surface velocities are stronger [Blanke and Delecluse, 1993]. On the other hand, vertical mixing below the mixed layer is more intense in case CVD than in the standard case. The core of the EUC is then slower and shallower [Blanke and Delecluse, 1993]. Furthermore, this current extends about $50 \mathrm{~m}$ deeper than in the standard case. At the surface, both sensitivity tests predict a zonal velocity field that does not compare as well with the drifter-derived climatology from Reverdin et al. [1994] as does the field simulated in the standard case (Figure 2). In particular, the SEC pre- dicted in case HV does not exhibit a minimum along the equateur, which results from an EUC that is too slow. In case CVD, zonal speeds of the SEC are too high. They can exceed $0.8 \mathrm{~m} \mathrm{~s}^{-1}$, whereas in the climatology, maximum speeds are about $0.4 \mathrm{~m} \mathrm{~s}^{-1}$.

Figure 4 includes the water mass budgets for both sensitivity tests. In case HV, water fluxes exhibit two major differences relative to those from the standard case. First, the EUC is weaker, bringing in $29.5 \mathrm{~Sv}$ instead of $33.3 \mathrm{~Sv}$ for the standard case. This decrease is not apparent in the total mass transport between 50 and $430 \mathrm{~m}$ because the deepest part of the westward flowing SEC is also slower in case HV (Figure 1). Secondly, in case HV, upwelling from the deep ocean (i.e., at the base of deep box) increases ninefold, to $1.8 \mathrm{~Sv}$. In case CVD, the most noticeable difference is the $36 \%$ increase in upwelling at $50 \mathrm{~m}$. Such a result might be expected, given the study by Blanke and Delecluse [1993] who show a $66 \%$ increase of the near-surface upwelling at the equator in a tropical Atlantic version of OPA, when a more classical Richardson number based schëıne is used instead of TKE to describe vertical turbulence. The slower horizontal near-surface velocities with the TKE scheme leads to a weaker near-surface upwelling. In the surface box, the zonal mass transport at $130^{\circ} \mathrm{W}$ is not substantially different from that of the standard case, despite a much faster SEC. In fact, the shallower EUC compensates this increased eastward transport. In the intermediate box, the larger vertical extent of the EUC explains the slightly increased eastward transport relative to the standard case, despite slower maximum zonal velocities.

Figure 6 includes an equatorial section of total phosphorus for each of the two sensitivity runs. Case HV exhibits a substantial increase in nutrient trapping. For example, total phosphorus concentrations exceed 4.4 $\mu \mathrm{mol} \mathrm{L}-1$ at $400 \mathrm{~m}$ along the American coast; in the standard run, total $\mathbf{P}$ concentrations reach, at most, $3.7 \mu \mathrm{mol} \mathrm{L}^{-1}$. Since the EUC is weaker, upwelled waters are more efficiently enriched in nutrients from remineralization of sinking particles. As a consequence, mean phosphorus concentration in the intermediate box is $0.34 \mu \mathrm{mol} \mathrm{L}^{-1}$ higher than in the standard case (Figure $7 \mathrm{~b}$ ). Case HV's P-enriched EUC causes $P$ transport by that current to be $19 \%$ higher, despite the lower EUC intensity. Thus waters upwelled to the surface in case HV have a much higher nutrient content. Resulting higher export production $(+11 \%)$ and the larger inflow of nutrient-rich waters from the deep ocean explain increased nutrient trapping.

For case CVD, there is no increase in nutrient trapping. Surprisingly, maximum phosphorus concentrations $\left(3.4 \mu \mathrm{mol} \mathrm{L}{ }^{-1}\right)$ are even lower than in the standard case $\left(3.7 \mu \mathrm{mol} \mathrm{L}^{-1}\right)$. Such a result is difficult to explain using the Najjar et al. [1992] analysis (Figure 8), which suggests that a more intense near-surface 
a)

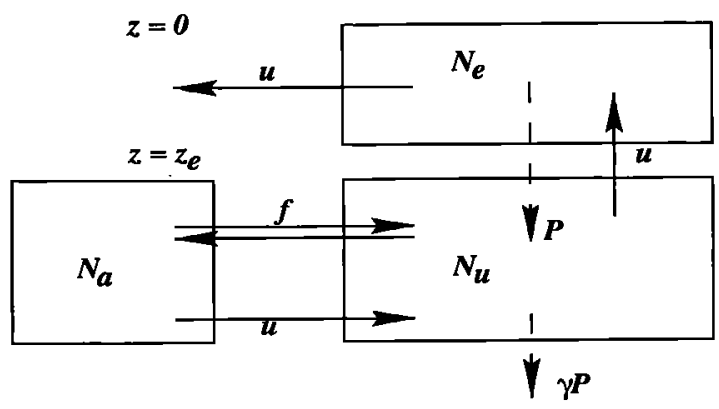

b)

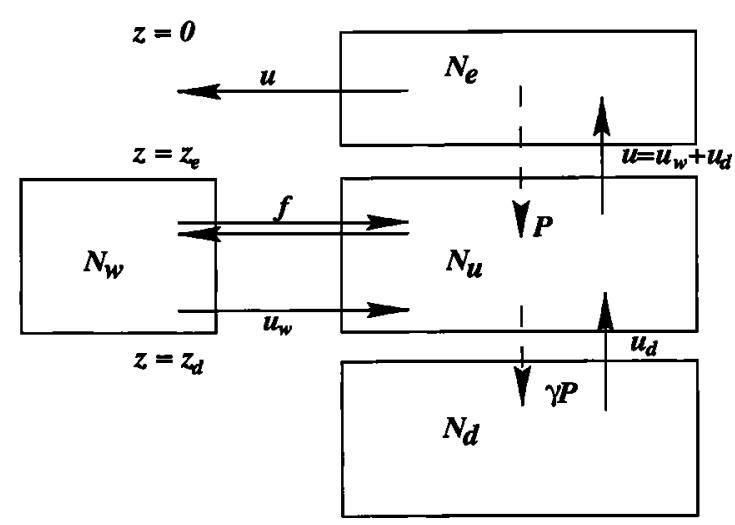

Figure 8. (a) Box model redrawn from Najjar et al. [1992] to determine processes involved in nutrient trapping. $N_{u}, N_{e}$, and $N_{a}$ represent the nutrient concentrations $\left(\mu \mathrm{mol} \mathrm{m}{ }^{-3}\right)$ of the upwelled waters, the euphotic zone, and the region from which the upwelled waters originate (ambient waters), respectively. $P$ is the production exported below the euphotic zone $\left(\mathrm{mol} \mathrm{s}^{-1}\right) ; \gamma$ is the fraction of $P$ that is not remineralized within the divergence zone; $u$ is the intensity of the divergence $\left(\mathrm{m}^{3} \mathrm{~s}^{-1}\right)$; and $f$ is the mixing intensity between the upwelled waters and the ambient waters $\left(\mathrm{m}^{3} \mathrm{~s}^{-1}\right)$. (b) Our revised version of the box model. The reservoir corresponding to the ambient waters (formerly with nutrient concentration $N_{a}$ ) has been split into two separate reservoirs that act in an opposing manner upon nutrient trapping. These are the western Pacific and the deep ocean, whose nutrient concentrations are denoted as $N_{w}$ and $N_{d}$, respectively. New advective terms describe transport by the EUC $u_{w}$, upwelling of abyssal waters $\mathrm{u}_{d}$, and near-surface upwelling $u_{s}$, all in units of $\mathrm{m}^{3} \mathrm{~s}^{-1}$. Other processes and symbols included in our revised model are identical to those in Figure 8a.

upwelling, such as found in this case, should increase nutrient trapping. The nutrient budget (Figure 7c) allows a better understanding. Although near-surface upwelling is greater, so is the intensity of the EUC because of its larger vertical extent. The EUC's increase in flow is modest at $130^{\circ} \mathrm{W}$ (about $5 \%$ ) but at $150^{\circ} \mathrm{W}$, closer to the source, the EUC is $12 \%$ stronger than in the standard case. As a consequence, the dilution induced by the EUC is stronger, so that nutrient concentrations of the upwelled waters are about $0.2 \mu \mathrm{mol} \mathrm{L}^{-1}$ lower than in the standard case. Thus, despite greater upwelling, export production remains almost unchanged (less than a $2 \%$ increase). In the deepest box, the downwelling $(0.5 \mathrm{~Sv})$ of less nutrient rich water than in the standard case compensates the more than doubled inflow from the deep ocean. Such result shows that different circulations can result in a significant decrease in nutrient trapping. However the circulation predicted in case CVD is less realistic than in the standard case. Thus a more realistic circulation is a sufficient but not a necessary condition to reduce nutrient trapping.

\section{Discussion}

\subsection{Nutrient Trapping: The Dynamic Solution}

Nutrient trapping is highly sensitive to the excess upwelling of abyssal water into the upper equatorial $\mathrm{Pa}$ cific. Our case HV shows that the rate of a model's abyssal upwelling is linked to its viscosity coefficients, which are tied to the model's chosen horizontal resolution. Coarse-resolution models that simulate nutrient trapping produce excess upwelling of abyssal water to the surface tropical Pacific, roughly $4 \mathrm{~Sv}$ in the GFDL model [Toggweiler et al., 1991; Toggweiler and Samuels, 1993] and $10 \mathrm{~Sv}$ in the LSG model [MaierReimer et al., 1993]. Coral records of ${ }^{14} \mathrm{C}$ show that such upwelling is unrealistic [Toggweiler et al., 1991]. Excess upwelling of abyssal water directly influences nutrient trapping. By bringing up large amounts of phosphate-rich deep water to the surface equatorial $\mathrm{Pa}$ cific ocean, deep upwelling of abyssal waters enhances export production, which enhances middepth $\mathrm{PO}_{4}^{3-}$ concentrations and thus the supply of $\mathrm{PO}_{4}^{3-}$ to the equatorial divergence. Fewer nutrients are able to escape the system.

Nutrient trapping is also related to the intensity of EUC. Yet the EUC acts indirectly because it lies above regions where nutrient trapping occurs. By advecting waters originating from the western part of the equatorial Pacific Ocean, the EUC dilutes the nutrient-rich waters that are upwelled to the surface. In that manner, EUC limits the intensity of export production and thus the amount of nutrient released during remineralization in subsurface waters. Despite stronger near surface upwelling in case CVD, a corresponding increase of the intensity of the EUC maintained export production at a level similar to that found in the standard case. Conversely, decreased EUC flow in case HV results in a substantial increase of phosphorus below the divergence and, consequently, in a significant increase $(+16 \%)$ of export production relative to the standard case. Coarse-resolution models are capable of producing only a weak EUC: a maximum speed of less than $0.2 \mathrm{~m} \mathrm{~s}^{-1}$ in the case of the GFDL model [Toggweiler et al., 1991] and of about $0.5 \mathrm{~m} \mathrm{~s}^{-1}$ in the case of the LSG model (E. Maier-Reimer, personal communication, 
1998). A weak EUC results in higher $\mathrm{PO}_{4}^{3-}$ at the sea surface, higher export production, and higher remineralization. Thus models with weak EUC tend to generate the artifact known as nutrient trapping.

Both the weaker EUC and excess upwelling of abyssal water found in coarse-resolution models can be related to Najjar et al.'s [1992] analysis of nutrient trapping. They explain their 3-D model results in the context of a simple box model of the upper equatorial Pacific Ocean (Figure 8a). Najjar et al. [1992] show that the nutrient concentration of the ambient region from which upwelled water originates $\left(N_{a}\right)$ is a determining factor for nutrient trapping. With lower $N_{a}$, there is less nutrient trapping. Both a strong EUC and little or no upwelling of deep water [Toggweiler et al., 1991] are found in the real ocean and in OPA. Both factors lead to lower $N_{a}$. A higher $N_{a}$ exists in coarse-resolution models because of their weak EUC and their large upwelling of abyssal water. Najjar et al. [1992] further point out that nutrient trapping increases with the proportion of organic matter remineralized within the divergence zone. In coarseresolution models, that proportion is increased because additional organic matter is remineralized within the upwelled abyssal waters during their passage to the surface. That excess remineralization produces excess nutrient that is reinjected into the divergence zone. The same phenomenon would occur if the divergence zone extended too deeply in the model.

Another factor is the near-surface upwelling. In their simple box model, Najjar et al. [1992] show that a more intense near-surface upwelling $u$ should increase nutrient trapping. In our case CVD, near-surface upwelling increases but subsurface nutrient buildup decreases. In this case, the Najjar et al. [1992] simple nutrient trapping model fails. The reason is that for case CVD, the EUC is also more intense. For our simulations, where the equatorial circulation is more realistic, nearsurface upwelling appears not to be a primary factor. We thus offer a slight revision to Najjar et al.'s [1992] box model, in which the EUC and the upwelling of abyssal waters are separated into two distinct processes (Figure 8b). As before, $N_{u}$ declines as the intensity of the EUC $u_{w}$ ) increases and as deep upwelling $u_{d}$ decreases. Such changes are equivalent to decreasing $N_{a}$ in the box model of Najjar et al. [1992] because phosphate concentrations in the deep ocean are much higher (typically $3 \mu \mathrm{mol} \mathrm{L}^{-1}$ ) than those in the regions where the EUC originates (less than $2 \mu \mathrm{mol} \mathrm{L}^{-1}$ ). Near-surface upwelling $u_{s}$ plays a small role.

\subsection{Implications for the Carbon Cycle}

Modeling results presented here show that a realistic nutrient distribution can indeed be simulated both in surface and subsurface waters but with a simple particle-only biogeochemical model. Absence of substantial excess phosphate below the divergence suggests that OPA-HAMOCC3 does not significantly overpredict vertical export by sinking particles. Our results suggest that export of DOC does not play a dominant role in the carbon budget of the equatorial $\mathrm{Pa}$ cific Ocean. In OPA, vertical export of POC (0.6 $\mathrm{PgC} \mathrm{yr}^{-1}$ ) represents $55 \%$ of the total DIC drawdown for the region between $170^{\circ} \mathrm{E}$ and $80^{\circ} \mathrm{W}$ and between $5^{\circ} \mathrm{S}$ and $5^{\circ} \mathrm{N}$; loss by air-sea exchange (0.48 $\left.\mathrm{Pg} \mathrm{C} \mathrm{yr}^{-1}\right)$ represents the remaining $45 \%$. The measured results from Hansell et al. [1997] are similar (53\% by POC export, $41 \%$ by air-sea exchange). The form and lifetime of DOC also provide information about its relative importance in the carbon budget. Most of the DOC in the ocean exists in refractory form [Murray et al., 1994; Carlson and Ducklow, 1995] whose mean lifetime is several thousand years [Williams and Druffel, 1987; Druffel et al., 1992]. Because of its long lifetime, refractory DOC has negligible impact on the carbon budget of the equatorial Pacific. However, there also exists a semilabile form of DOC found mostly within the top few hundred meters of the ocean. The lifetime of the semilabile DOC has been estimated to be 30-120 days [Archer et al., 1997]. Given such a short lifetime, how far might the semilabile DOC be able to travel? In OPA, the upwelling rate is $38 \mathrm{~Sv}$ at $50 \mathrm{~m}$ for the region between $5^{\circ} \mathrm{S}$ to $5^{\circ} \mathrm{N}$ and $100^{\circ} \mathrm{W}$ to $170^{\circ} \mathrm{E}$. The mean residence time of waters in this region is about $\mathbf{1 7 0}$ days, which is at least $50 \%$ longer than mean lifetime of semilabile DOC. Thus most semilabile DOC is remineralized before it has a chance to be advected out of the equatorial region.

Such a rapid turnover rate ( 2 months) explains why observed semilabile DOC concentrations increase by only $10 \mu \mathrm{mol} \mathrm{L}^{-1}$ between the equator and $5^{\circ}$ [Archer et al., 1997]. A $38 \mathrm{~Sv}$ water outflux having $10 \mu \mathrm{mol} \mathrm{DOC}$ $\mathrm{L}^{-1}$ yields a lateral export of about $0.15 \mathrm{PgC} \mathrm{yr}^{-1}$. This estimate is one fourth of OPA's export associated with sinking particles $\left(0.6 \mathrm{Pg} \mathrm{C} \mathrm{yr}^{-1}\right)$ and slightly less than the 0.2-0.4 $\mathrm{PgC} \mathrm{yr}^{-1}$ proposed by Archer et al. [1997], who used a model of the tropical $\mathrm{Pa}$ cific that includes DOC. Adding this $0.15 \mathrm{PgC} \mathrm{yr}^{-1}$ export of $\mathrm{DOC}$ to the $1.08 \mathrm{Pg} \mathrm{C} \mathrm{yr}^{-1}$ carbon loss predicted by OPA-HAMOCC3 ( $0.6 \mathrm{Pg} \mathrm{C} \mathrm{yr}^{-1}$ as POC, 0.48 $\mathrm{PgC} \mathrm{yr}^{-1}$ by air-sea exchange) leads to a total export of $1.23 \mathrm{Pg} \mathrm{Cyr}^{-1}$ out of the surface equatorial Pacific. According to this simple recipe, DOC contributes only $12 \%$ of total carbon export out of the equatorial $\mathrm{Pa}$ cific Ocean. This small contribution of DOC is similar to the $10 \%$ maximum proposed by Hansell et al. [1997]. Therefore DOC seems to play a minor role in the carbon budget of the equatorial Pacific.

\section{Conclusions}

The OPA-HAMOCC3 model predicts phosphate concentrations in the subsurface equatorial Pacific that exceed the observed nutrient concentrations by, at most, 
$15 \%$; other coarse-resolution models predict large excess nutrient concentrations (nutrient trapping) in this same region. OPA's improvement is due to its higher meridional resolution $\left(0.5^{\circ} \mathrm{N}-\mathrm{S}\right)$ near the equator, which allows (1) a vigorous equatorial undercurrent (EUC) in the Pacific and (2) a reduction of upwelling of abyssal water to the surface. Both effects reduce nutrient trapping. The EUC brings in low-nutrient waters from the western Pacific, diluting concentrations in the east. Reduced abyssal upwelling cuts off the supply of nutrientrich waters from below. Other global-scale carbon-cycle models have inadequate resolution to properly represent circulation features in the equatorial Pacific, such as the fine-scale intense EUC, which are prerequisites to getting the nutrient distribution right. Although previously suggested improvements to the biogeochemical model act to improve nutrient trapping, their necessity cannot be correctly evaluated until the circulation model does a proper job at representing equatorial dynamics. To avoid nutrient trapping, coarse-resolution models will have to employ higher meridional resolution at the equator. Simulations with a coarser-resolution version of OPA [Braconnot et al., 1997] suggest that $1^{\circ}$ meridional resolution is adequate. Nonetheless, if an enhanced meridional resolution concurs to reduce nutrient trapping, lack of nutrient trapping should not be considered as an indication of a realistic circulation.

We have shown that a realistic distribution of surface and subsurface $\mathrm{PO}_{4}^{3-}$ in the equatorial Pacific can be achieved in a model having only a particle-only remineralization scheme. These model results suggest that DOC does not play a dominant role in the carbon budget of the equatorial Pacific. According to our modelbased calculations, DOC accounts for only about $12 \%$ of the total carbon export out of the equatorial Pacific region. Recent observational constraints suggest that DOC is responsible for, at most, $10 \%$ the total carbon transport out of the same region [Hansell et al., 1997].

Acknowledgments. We sincerely thank C. Le Quéré, L. Memery, and N. Metzl for suggestions and comments that have improved this manuscript. We thank R. G. Najjar for his review of the manuscript. Support for computations was provided by CEA/DSM and by CNRS/IDRIS. This work was funded by the Environment and Climate Programme of the European Community (ESCOBA-Ocean contract ENV4-CT95-0132).

\section{References}

Anderson, L. A., and J. L. Sarmiento, Global ocean phosphate and oxygen simulations, Global Biogeochem. Cycles, 9, 621-636, 1995.

Andrich, P., OPA - A multitasked Ocean General Circulation Model, Reference manual, LODyC, Université Paris VI, Paris, FRANCE, 1988.

Arakawa, A., and V. R. Lamb, Computational design of the UCLA general circulation model, Methods Comput. Phys., $16,173-283,1977$.
Archer, D., E. T. Peltzer, and D. L. Kirchman, A timescale for dissolved organic carbon production in equatorial $\mathrm{Pa}$ cific waters, Global Biogeochem. Cycles, 11, 435-452, 1997.

Aumont, O., J. C. Orr, D. Jamous, P. Monfray, O. Marti, and G. Madec, A degradation approach to accelerate simulations to steady state in a 3-D tracer transport model of the global ocean, Clim. Dyn., 14, 101-116, 1998.

Bacastow, R., and E. Maier-Reimer, Ocean-circulation model of the Carbon cycle, Clim. Dyn., 4, 95-125, 1990.

Bacastow, R., and E. Maier-Reimer, Dissolved organic carbon in modeling oceanic new production, Global Biogeochem. Cycles, 5, 71-85, 1991.

Berger, W. H., K. Fischer, C. Lai, and G. Wu, Ocean productivity and organic carbon flux, part I, Overview of maps of primary production and export production, Sio ref. 87-30, Univ. of Calif., San Diego, 1987.

Blanke, B., and P. Delecluse, Low frequency variability of the tropical Atlantic ocean simulated by a general circulation model with mixed layer physics, J. Phys. Oceanogr., 23, 1363-1388, 1993.

Blanke, B., and S. Raynaud, Kinematics of the Pacific Equatorial Undercurrent: an Eulerian and Lagrangian approach from GCM results, J. Phys. Oceanogr., 27, 10381053, 1997.

Boutin, J., and J. Etcheto, Long-term variability of the airsea $\mathrm{CO}_{2}$ exchange coefficient: Consequences for the $\mathrm{CO}_{2}$ fluxes in the equatorial Pacific Ocean, Global Biogeochem. Cycles, 11, 453-470, 1997.

Braconnot, P., O. Marti, and S. Joussaume, Adjustement and feedbacks in a global coupled ocean-atmosphere model, Clim. Dyn., 13, 507-519, 1997.

Broecker, W. S., and T. H. Peng, Tracers in the Sea, 691 pp., Lamont-Doherty Earth Observatory, Palisades, 1982.

Broecker, W. S., T. S. Peng, G. Östlund, and M. Stuiver, The distribution of bomb radiocarbon in the ocean, $J$. Geophys. Res., 90, 6953-6970, 1985.

Buesseler, K. O., M. P. Bacon, J. K. Cochran, and H. D. Livingston, Carbon and nitrogen export during the JGOFS North Atlantic Bloom Experiment estimated from ${ }^{234} \mathrm{Th}$, Deep Sea Res., Part II, 39, 1115-1137, 1992.

Carlson, C. A., and H. W. Ducklow, Dissolved organic carbon in the upper ocean of the central equatorial Pacific Ocean, 1992: Daily and finescale vertical variations, Deep Sea Res., Part II, 42, 639-656, 1995.

Chavez, F. P., and R. T. Barber, An estimate of new production in the Equatorial Pacific, Deep Sea Res., Part A, 34, 1129-1243, 1987.

Coale, $K, H$., et al., A massive phytoplankton bloom induced by an ecosystem-scale iron fertilization experiment in the equatorial Pacific Ocean, Nature, 383, 495-501, 1996.

Conkright, M. E., S. Levitus, and T. P. Boyer, NOAA Atlas NESDIS 1: World ocean atlas 1994, vol. 1, Nutrients, technical report, Natl. Oceanic and Atmos. Admin., Silver Spring., Md., 1994.

Delecluse, P., M. Imbard, C. Lévy, and G. Madec, OPAOcean General Circulation model, reference manual, Lab. Océ. Dyn. Clim., Univ. Paris VI, Paris, 1993.

Druffel, E. R. M., P. M. Williams, J. E. Bauer, and J. R. Ertel, Cycling of dissolved and particulate organic matter in the open ocean, J. Geophys. Res., 97, 15639-15659, 1992.

Dugdale, R. C., Nutrient limitation in the sea: Dynamics, identification, and significance, Limnol. Oceanogr., 12, 685-695, 1967.

Fujio, S., and N. N. Imasato, Diagnostic calculation for cir- 
culation and water mass movement in the deep Pacific, $J$. Geophys. Res., 96, 759-774, 1991.

Gammon, R. H., E. T. Sundquist, and P. J. Fraser, History of carbon dioxide in the atmosphere, Atmospheric Carbon Dioxide and the Global Carbon Cycle, 1985.

Gaspar, P., Y. Gregoris, and J. M. Lefevre, A simple eddy kinetic energy model for simulations of the ocean vertical mixing: Tests at station Papa and Long-Term Upper Ocean Study Site site, J. Geophys. Res., 95, 16,17916,193, 1990.

Guilyardi, E., and G. Madec, Performance of the OPA/ARPEGE-T21 global ocean atmosphere coupled model, Clim. Dyn., 13, 149-165, 1997.

Hansell, D. A., N. R. Bates, and C. A. Carlson, Predominance of vertical loss of carbon from surface waters of the equatorial Pacific Ocean, Nature, 386, 59-61, 1997.

Hellerman, S., and M. Rosenstein, Normal monthly wind stress over the world ocean with error estimates, J. Phys. Oceanogr., 13, 1093-1104, 1983.

Levitus, S., Climatological atlas of the world ocean, NOAA Prof. Pap. 13, U. S. Govt. Print. off, Washington D.C., 1982.

Liss, P. S., and L. Merlivat, Air-sea gas exchange rates: introduction and synthesis, in The role of air-sea gas exchange in geochemical cycling, NATO ASI Ser., vol. 185, edited by P. Buat-Menard, pp. 113-127, D. Reidel, Norwell, Mass., 1986.

Lukas, R., The termination of the Equatorial Undercurrent in the Eastern Pacific, Prog. Oceanogr., 16, 63-90, 1986.

Madec, G., and M. Imbard, A global ocean mesh to overcome the North Pole singularity, Clim. Dyn., 12, 381-388, 1996.

Maes, C., G. Madec, and P. Delecluse, Sensitivity of an equatorial Pacific OGCM to the lateral diffusion, Mon. Weather Rev., 125, 958-971, 1997.

Maier-Reimer, E., Geochemical cycles in an ocean general circulation model: Preindustrial tracer distributions, Global Biogeochem. Cycles, 7, 645-677, 1993.

Maier-Reimer, E., U. Mikolajewicz, and K. Hasselmann, Mean circulation of the Hamburg LSG OGCM and its sensitivity to the thermohaline surface forcing, $J$. Phys. Oceanogr., 23, 731-757, 1993.

Marti, O., Etude de l'océan mondial: Modélisation de la circulation et du transport des traceurs anthropiques, Ph.D. thesis, Univ. Paris VI, Paris, 1992.

Marti, O., G. Madec, and P. Delecluse, Comment on net "Net diffusivity in ocean general circulation models with non uniform grids" by F. L. Yin and I. Y. Fung, J. Geophys. Res., 97, 12763-12766, 1992.

Matear, R. J., and G. Holloway, Modeling the inorganic phosphorus cycle of the North Pacific using an adjoint data assimilation model to assess the role of dissolved organic phosphorus, Global Biogeochem. Cycles, 9, 101-119, 1995.

Murray, J. W., R. T. Barber, M. R. Roman, M. P. Bacon, and R. A. Feely, Physical and biological controls on carbon cycling in the equatorial Pacific, Science, 266, 58-65, 1994.

Murray, J. W., J. Young, J. Newton, J. Dunne, T. Chapin, B. Paul, and J. J. McCarthy, Export flux of particulate organic carbon from the central equatorial Pacific determined using a combined drifting trap- ${ }^{234} \mathrm{Th}$ approach, Deep Sea Res., Part II, 43, 1095-1132, 1996.

Najjar, R. G., Simulations of the phosphorus and oxygen cycles in the world ocean using a general circulational model, Ph.D. thesis, Princeton Univ., Princeton, N. J., 1990.
Najjar, R. G., J. L. Sarmiento, and J. R. Toggweiler, Downward transport and fate of organic matter in the ocean: Simulations with a general circulation model, Global Biogeochem. Cycles, 6, 45-76, 1992.

Oberhüber, J. M., An atlas on the 'COADS' data set: The Budget of Heat, Buoyancy, and Turbulent Kinetic Energy at the Surface of the Global Ocean, chap. 15, Max-Planck Inst. für Meteorol., Hamburg, Germany, 1988.

Poulain, P. M., Estimates of horizontal divergence and vertical velocity in the equatorial Pacific, J. Phys. Oceanogr., 23, 601-607, 1993.

Qiao, L., and R. H. Weisberg, The zonal momentum balance of the equatorial undercurrent in the central Pacific, $J$. Phys. Oceanogr., 27, 1094-1119, 1997.

Reverdin, G., C. Frankignoul, E. Kestenare, and M. J. McPhaden, Seasonnal variability in the surface currents of the equatorial Pacific, J. Geophys. Res., 99, 20,32320,344, 1994.

Six, K. D., and E. Maier-Reimer, Effects of plankton dynamics on seasonal carbon fluxes in an ocean general circulation model, Global Biogeochem. Cycles, 10, 559-583, 1996.

Smolarkiewicz, K. P., The multidimensional Crowley advection scheme, Mon. Weather Rev., 110, 1968-1983, 1982.

Smolarkiewicz, K. P., A simple positive advection scheme with small implicit diffusion, Mon. Weather Rev., 111, 479-486, 1983.

Smolarkiewicz, K. P., and T. L. Clark, The multidimensional positive definite advection transport algorithm: Further development and applications, J. Comput. Phys., 67, 396438, 1986.

Sugimura, Y., and Y. Suzuki, A high-temperature catalytic oxidation method for the determination of non-volatile dissolved carbon in seawater by direct injection of a liquid sample, Mar. Chem., 24, 105-131, 1988.

Suzuki, Y., On the measurement of DOC and DON in seawater, Mar. Chem., 41, 287-288, 1993.

Suzuki, Y., Y. Sugimura, and T. Itoh, A catalytic oxidation method for the determination of total nitrogen dissolved in seawater, Mar. Chem., 16, 83-97, 1985.

Takahashi, T., W. S. Broecker, and A. E. Bainbridge, The alkalinity and total carbon dioxide concentration in the World Oceans, in Carbon Cycle Modeling in Scope, edited by B. Bolin, pp. 271-286, John Wiley, New York, 1981.

Toggweiler, J. R., and S. Carson, What are upwelling systems contributing to the ocean's carbon and nutrient budget?, in Upwelling in the Ocean: Modern Processes and Ancient records, edited by C. Summerhayes et al., pp. 337-360, John Wiley, New York, 1995.

Toggweiler, J. R., K. Dixon, and W. S. Broecker, The Peru upwelling and the ventilation of the South Pacific thermocline, J. Geophys. Res., 96, 20467-20497, 1991.

Toggweiler, J. R., K. Dixon, and K. Bryan, Simulations of radiocarbon in a coarse-resolution world ocean model, 2, Steady state prebomb distribution, J. Geophys. Res., 94, 8217-8242, 1989.

Toggweiler, J. R., and B. Samuels, New radiocarbon constraints on the upwelling of abyssal water to the ocean's surface, in The Global Carbon Cycle, NATO ASI Ser., Ser. I, vol. 15, edited by M. Heimann, pp. 333-366, Springer-Verlag, New York, 1993.

Tsuchiya, M., The origin of the Pacific Equatorial $13^{\circ} \mathrm{C} \mathrm{Wa-}$ ter, J. Phys. Oceanogr., 11, 794-812, 1981.

Wanninkhof, R., Relationship between wind speed and gas exchange over the ocean, J. Geophys. Res., 97, 7373-7382, 1992. 
Wentz, F. J., Measurements of oceanic wind vector using satellite microwave radiometers, IEEE Trans. Geosci. Remote Sens., 30, 960-972, 1992.

Williams, P. M., and E. R. M. Druffel, Radiocarbon in dissolved organic matter in the central Pacific Ocean, Nature, 330, 246-248, 1987.

Winguth, A. M. E., M. Heimann, K. D. Kurz, E. MaierReimer, U. Mikolajewicz, and J. Segschneider, El-niñoSouthern Oscillation related fluctuations of marine carbon cycle, Global Biogeochem. Cycles, 8, 39-63, 1994.

Wong, C. S., Y. H. Chan, J. S. Page, G. E. Smith, and R. D. Bellegay, Changes in equatorial $\mathrm{CO}_{2}$ flux and new production estimated from $\mathrm{CO}_{2}$ and nutrients levels in Pacific surface waters during 1986/87 El Niño, Tellus, 45, 64-79, 1993.

Wyrtki, K., The horizontal and vertical field of motion in the Peru current, Bull. Scripps Inst. Oceanogr., 8, 313346, 1963.

Wyrtki, K., An estimate of equatorial upwelling in the $\mathrm{Pa}$ cific, J. Phys. Oceanogr., 11, 1205-1214, 1981.

Wyrtki, K., and B. Kilonsky, Mean water and current structure during the Hawaii-to-Tahiti shuttle experiments, $J$. Phys. Oceanogr., 14, 251-253, 1984.

Yamanaka, Y., and E. Tajika, The role of the vertical fluxes of particulate organic matter and calcite in the oceanic carbon cycle: Studies using an ocean biogeochemical general circulation model, Global Biogeochem. Cycles, 10, 361-382, 1996.

Yamanaka, Y., and E. Tajika, Role of dissolved organic matter in the marine biogeochemical cycle: Studies using an ocean biogeochemical model, Global Biogeochem. Cycles, 11, 599-612, 1997.

O. Aumont, J. C. Orr, and P. Monfray, Laboratoire des Sciences du Climat et de l'Environnement, DSM, CE Saclay, CEA, L'Orme des Merisiers, Bâtiment 709, F-91191 Gif sur Yvette, Cedex, France. (e-mail: aumont@lsce.saclay.cea.fr, orr@lsce.saclay.cea.fr, monfray@lsce.saclay.cea.fr)

G. Madec, Laboratoire d'Océanographie Dynamique et de Climatologie, Université Paris VI, 4 place Jussieu, Paris, France. (e-mail: madec@lodyc.jussieu.fr)

E. Maier-Reimer, Max Planck Institut für Meteorologie, Bundesstrasse 55, D-20146 Hamburg, Germany. (e-mạil: maier-reimer@dkrz.de)

(Received January 2, 1998; revised October 12, 1998; accepted November 13, 1998.) 